\title{
Identifying Language Needs in Community-Based Adult ELLs: Findings from an Ethnography of Four Salvadoran Immigrants in the Western United States
}

Kathryn Anne Watkins

Brigham Young University

Follow this and additional works at: https://scholarsarchive.byu.edu/etd

Part of the Arts and Humanities Commons

BYU ScholarsArchive Citation

Watkins, Kathryn Anne, "Identifying Language Needs in Community-Based Adult ELLs: Findings from an Ethnography of Four Salvadoran Immigrants in the Western United States" (2020). Theses and Dissertations. 8526.

https://scholarsarchive.byu.edu/etd/8526

This Thesis is brought to you for free and open access by BYU ScholarsArchive. It has been accepted for inclusion in Theses and Dissertations by an authorized administrator of BYU ScholarsArchive. For more information, please contact ellen_amatangelo@byu.edu. 
Identifying Language Needs in Community-Based Adult ELLs:

Findings from an Ethnography of Four Salvadoran

Immigrants in the Western United States

Kathryn Anne Watkins

A thesis submitted to faculty of

Brigham Young University

in partial fulfillment of the requirements for the degree of

Master of Arts

William G. Eggington, Chair

Grant W. Eckstein

Gregory A. Thompson

Alessandro A. Rosborough

Department of Linguistics

Brigham Young University

Copyright (C) 2020 Kathryn Anne Watkins

All Rights Reserved 


\author{
ABSTRACT \\ Identifying Language Needs in Community-Based Adult ELLs: \\ Findings from an Ethnography of Four Salvadoran \\ Immigrants in the Western United States \\ Kathryn Anne Watkins \\ Department of Linguistics, BYU \\ Master of Arts
}

The United States is home to hundreds of thousands of refugees and immigrants who desire to learn English. In contrast to academically-focused English language learners (ELLs), or international students, refugee and immigrant ELLs are often dealing with the stresses of poverty and/or a precarious immigration status, giving them a diverse and complex set of needs that are often not adequately met by ESL programs. Building off a foundation of Activity Theory, Sociocultural Theory, and Language Ecology, which emphasizes an approach to language learning and teaching that does not separate language from the authentic contexts from which it arises (Van Lier, 2002; Leather \& Van Dam, 2003; Pennycook, 2010; Swain \& Watanabe, 2012; among others), I seek to uncover and address these needs in-context through an ethnography of six Spanish-speaking immigrant ELLs in the western United States. I detail the results of an indepth analysis of 116 hours of participant observation with these women, paying special attention to their daily routines and how, where, and why they employ English or Spanish. I show how the women's daily routines and participation in Latinx communities curtail much of their need for daily English, how they employ various strategies to get by when they do need English, and how their expressed motivations to learn English are often thwarted by their current life circumstances. I end by summarizing key observations about the ELLs in the study and making general recommendations to ESL programs for how to apply these observations.

Keywords: ethnography, ethnography of communication, linguistic ethnography, TESOL, language ecology, English language learners, community-based learners, adult ESL education 


\section{ACKNOWLEDGMENTS}

I would like to thank my committee members, my family, and my friends for providing me with invaluable help and support through each phase of the research, analysis, and thesiswriting process.

Most especially, I wish to thank my study participants, Luciana, Mariela, Julissa, Carmen, Ana, and Rocío, as well as their families, for opening their homes and lives to me and dedicating countless hours to working with me. They showed me kindness, offered me friendship, taught me skills I now cherish (such as how to make Salvadoran pupusas), fed me delicious meals, and supported me in every way. I am grateful for the opportunity I had to spend time with them and for the relationships I have built with them. 


\section{TABLE OF CONTENTS}

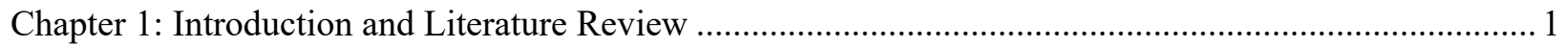

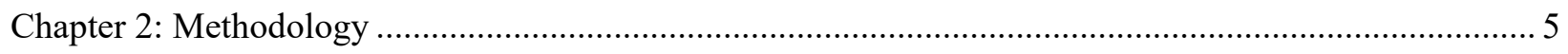

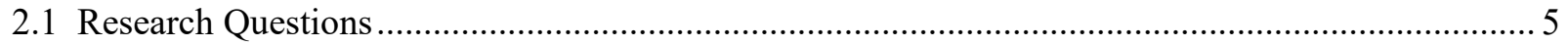

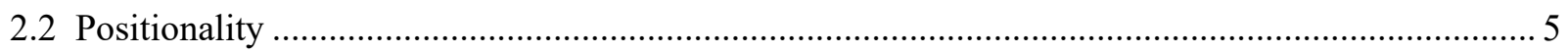

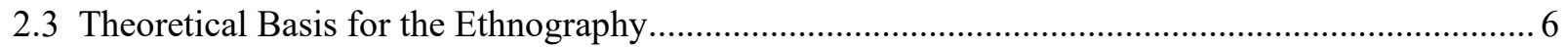

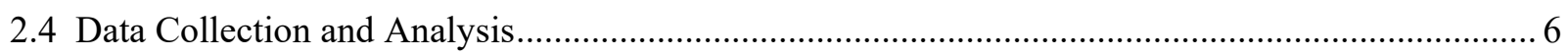

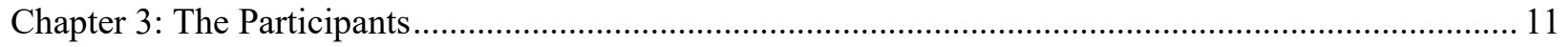

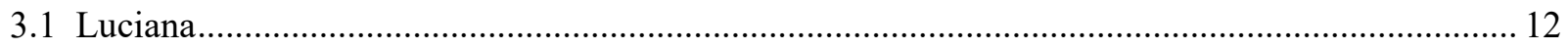

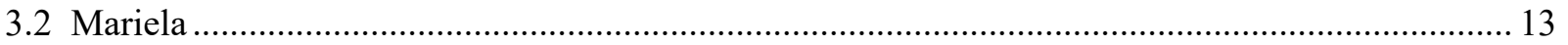

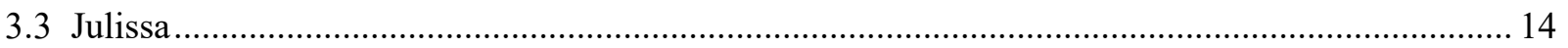

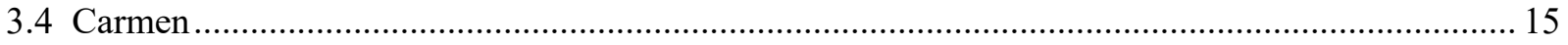

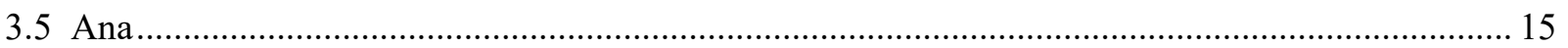

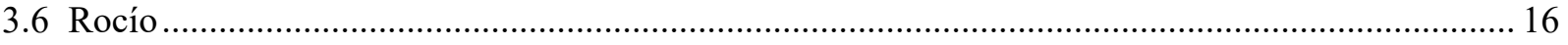

Chapter 4: Daily Routine and Language Use -- Addressing Research Question 1 ................................. 17

4.1 Enclave Participation and Situations Where English Was Not Required ..................................... 19

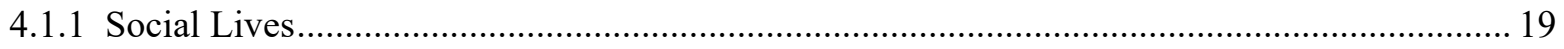

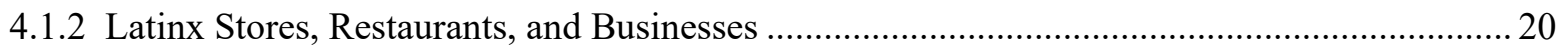

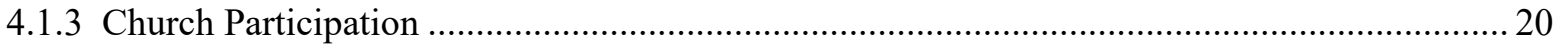

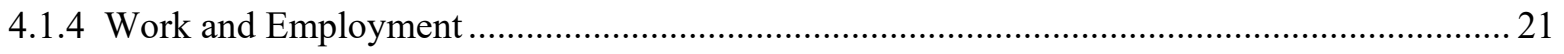

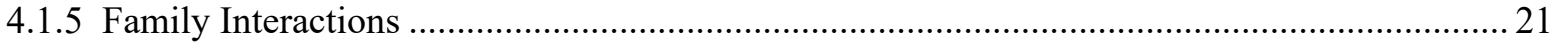

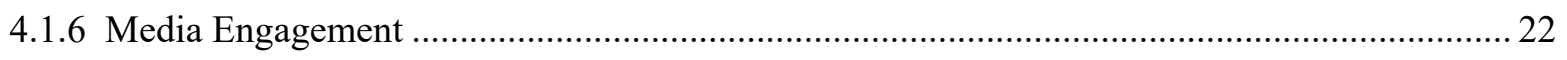

4.2 Daily Routines in the Enclaves and Beyond: When and Where English Was Used.......................22

4.2.1 American Establishments (Stores, Restaurants, Offices, Banks, and Schools) ...................... 23

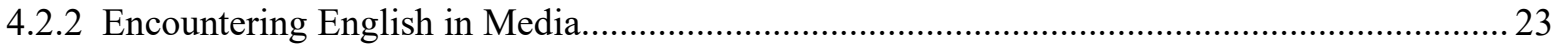

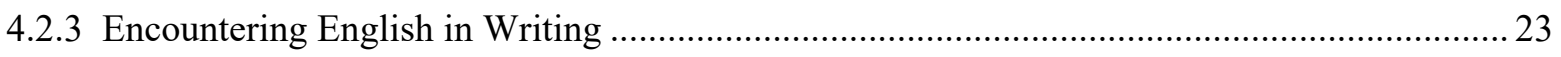

Chapter 5: Strategies for Getting By in English -- Addressing Research Question 2 ............................225

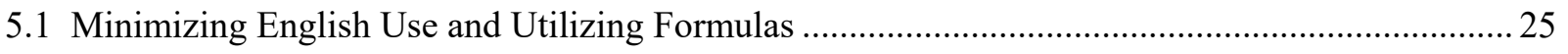

5.1.1 Minimization Strategy 1: Prefabricated Patterns …...............................................................26

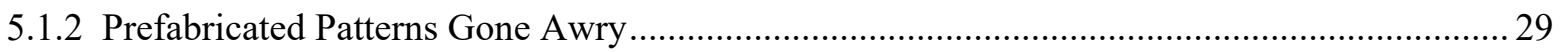




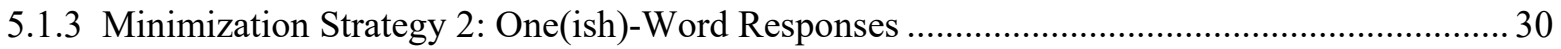

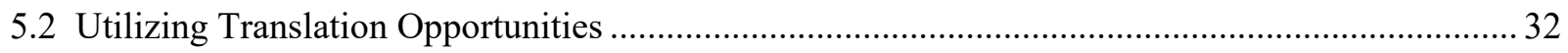

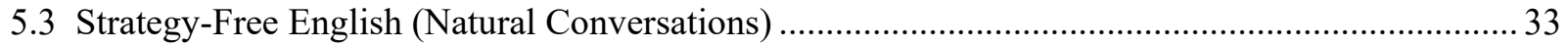

Chapter 6: Language Needs and the Participants' Stated Goals - Addressing Research Question 3 ......... 34

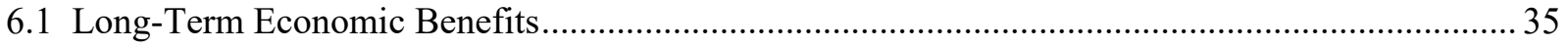

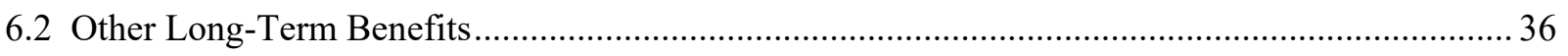

Chapter 7: Conclusions and Recommendations for ESL Programs for CBLs........................................ 37

7.1 Observation 1: Many CBLs have few opportunities to be immersed in English outside of school. 37

7.2 Observation 2: CBLs like the women in my study have a finite number of situations in which they

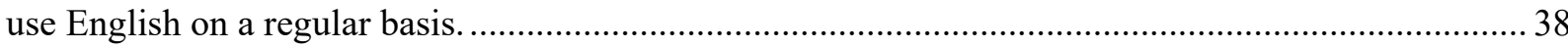

7.3 Observation 3: CBLs bring assets of many kinds to the table that ESL programs can take note of and capitalize on.

7.4 Limitations and Suggestions for Additional Studies.................................................................... 40

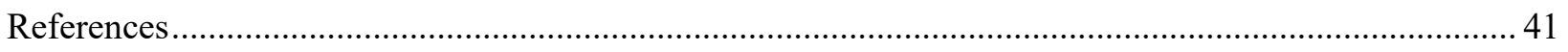

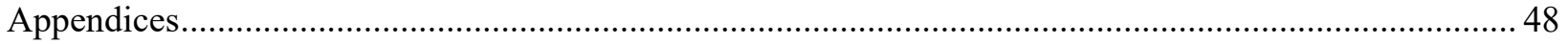

Appendix 1: Criteria for Defining a Community-Based ELL (Based on NCES standards for defining

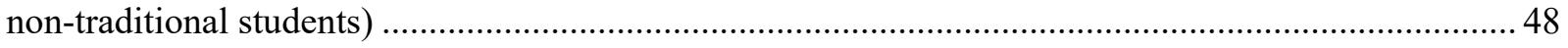

Appendix 2: MacMillan Straightforward Quick Placement Test.......................................................... 49

Appendix 3: Arguments/Themes and Supporting Evidences: .......................................................... 61

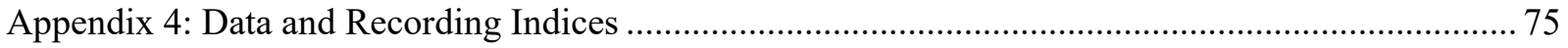

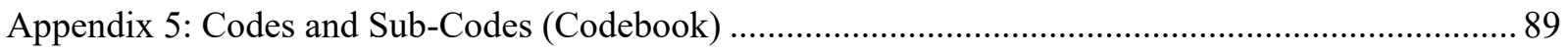

Appendix 6: Inventory of all individuals (pseudonyms) that appear in the study and how they relate to

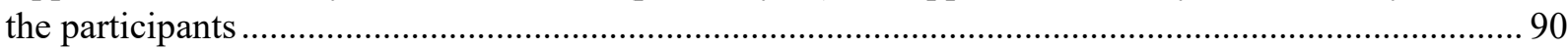

\section{LIST OF TABLES}

Table 1: Participant Visits to English- and Spanish-Speaking Venues..................................................18 


\section{Chapter 1: Introduction and Literature Review}

I am standing with Mariela, a 35-year-old Salvadoran immigrant, in her kitchen as she cooks a giant pot of chicken to take to church to feed the homeless. As we talk about why learning English is important to her, she speaks of expanding her vocabulary and learning how to express herself. "I'm trying to do this in the school I go to," she says in Spanish, "to learn to speak and to really get involved, not just in-- in restaurants, not just in Walmart, but with all types of people, with all types of conversation. This is what I'm trying to do but it's so hard. "She laughs. Sometimes, she tells me, she repeats the words, "Yo puedo inglés, (I can speak English) yo puedo inglés," over and over as a kind of mantra. She's pinned a piece of paper to her kitchen wall with the mantra written on it to inspire her. It is slightly ironic, I think, that her mantra about learning English is written and spoken in Spanish.

The United States is home to hundreds of thousands of refugees and immigrants who, like Mariela, desire to learn English, both for practical purposes and to be able to fulfill deeper goals and dreams. In contrast to academically-focused English language learners (ELLs), or international students, who are typically student visa holders and whose primary purpose in the US is to attend school, refugee and immigrant ELLs are often fleeing detrimental circumstances in their home countries and dealing with the stresses of poverty and/or a precarious immigration status as they try to build a permanent life here in the US. Many have families, full-time jobs, and other responsibilities that do not allow them to pursue a college- or university-level education or even to study English as a primary commitment. ${ }^{1}$ The complex needs of these ELLs (hereafter referred to as community-based learners, or CBLs) have often been overlooked. As a

\footnotetext{
${ }^{1}$ For a further discussion of the criteria I used for defining community-based ELLs, see Appendix 1 of this thesis and the National Center for Education Statistics article listed in the Reference section (NCES, n.d.). I used the criteria detailed in Appendix 1 to determine whether potential ELL research participants were eligible for this study.
} 
result, like Mariela, many CBLs are enrolled in ESL programs -- and have been for years -- but are seeing little or no improvement in their actual English ability.

One reason for this is that ESL programs are often a poor fit for the needs of CBLs: they may be too academically rigorous (Adult Education Interest Section, 2017), too rigidly practical and unstimulating (Auerbach, 1986), or focused on irrelevant content (Auerbach, 1992; Horton \& Freire, 1990; Van Lier, 2004). Even the most conscientious ESL programs may struggle to be effective when it comes to helping CBLs, and many of these difficulties stem from one root problem: ESL programs are often based on a cognitivist orientation to language learning that fails to take into account learners' complex realities (see Firth \& Wagner, 1997; Van Lier, 2008, among others).

As Pennycook (2000) points out, most language classrooms operate on the assumption that language is "a set of structures, pronunciations, or communicative acts that students need to master" (p. 89), or in other words, that language learning is, at its core, a cognitive process rather than a social, cultural, or political one (Firth \& Wagner, 1997; Freeman \& Johnson, 1998; Van Lier 2000, 2004, 2008a, 2011). This orientation has led to research on ELLs that is mostly limited to studies inside the classroom (see Richards and Rodgers, 1986; West, 1994; Khansir \& Pakdel, 2014), creating an "educational context separated from society" (Pennycook, 2000, p. 89) that ignores the larger context of language learning -- one that includes all the intersecting contexts, spheres, and realities of learners' lives. ${ }^{2}$

Many researchers, coming especially from the theoretical frameworks of Activity Theory, Sociocultural Theory, and Language Ecology, have pointed out the problems with separating

\footnotetext{
${ }^{2}$ It is worth noting that some ESL programs and organizations, such as the widely-used assessment organization CASAS (CASAS, 2017), do attempt to take learners' complex realities into account. However, even these programs tend to rely too heavily on classroom-based assessments and exams and thus are limited to only a narrow view of learners' needs.
} 
language learning from the cultural, social, and other contexts in which it exists naturally as part of an active process (Firth \& Wagner, 1997; Kramsch, 1992; Van Lier, 2004, 2008a; Leather \& Van Dam, 2003) and even with attempting to define language as an abstract entity or object separate from the actual situations in which it is used (Pennycook, 2010; Swain \& Watanabe, 2012). This separation can rob students of their agency as learners (Van Lier, 2004, 2008b), in addition to contributing to the problematic situations described above.

A more complete, helpful picture of the English learning process must acknowledge "that classrooms, both in themselves and in their relationship to the world beyond their walls, are complex social and cultural spaces... sociopolitical spaces that exist in a complex relationship to the world outside" (Pennycook, 2000, p. 89; see also Pennycook, 2010 and Van Lier, 2004) and that ESL instruction is necessarily a complex, context-driven endeavor (Warriner, 2007). Additionally, an effective approach to ESL learning and teaching must "draw out and emphasize community- and home-based knowledge, culture, and language" in its programs, building on the complex assets learners bring to the table from the broader contexts of their lives rather than ignoring these in favor of a top-down, cognitivist approach to learning (MacSwan, 2020, p. 29). It must also situate itself within contexts that are genuine and meaningful to students rather than oriented towards vague future usefulness. In this thesis, I refer to such contexts -- the places and situations where learners are already "doing” language -- as authentic contexts. I refer to the language being “done" and/or learned within these contexts as 'situated language,' a term coined by Gee (2004). Rich contextualized research on CBLs is needed to better design ESL programs to respond to these students' complex realities, interests, and needs (see Van Lier's discussion on democratic practices in second-language classrooms, 2004). 
In the study that follows, I chose to employ ethnographic research methods in order to generate in-depth data about the participants' linguistic and other experiences situated within a wide variety of real-life, everyday contexts. This research fills an important gap between the many existing classroom-based studies on ELLs, including those conducted by proponents of a sociocultural approach to language learning and research (examples include Donato \& MacCormick, 1994; Donato, 1994; Ohta, 1995; Lantolf \& Genung, 2002; Ganém Gutiérrez, 2008), and the many ethnographies that focus on ELL populations and produce rich data on their authentic experiences but without attending specifically to their language experiences or needs (examples include Margolis, 1993; Monzó, 2016, Colegrove, 2019; Gomberg-Muñoz, 2019). This gap has been partially addressed by studies following the ethnography of communication (EOC) model (Gumperz \& Hymes, 1986; Seville-Troike, 2008; Kvam, 2017). However, few, if any, of these studies directly address the situated language needs of learners in context, and some EOC studies are still classroom-based (examples include Duff 1995; 2002).

This thesis employs findings from six months of ethnographic research with six Spanishspeaking adult CBLs with the goal of documenting the language practices and needs of these learners based on their authentic life experiences. In what follows, I document the women's authentic experiences with navigating everyday linguistic interactions in Spanish and English. I show how the women's daily routines and participation in Latinx ${ }^{3}$ communities curtail much of their need for daily English, how they employ various strategies to get by when they do need English, and how their expressed motivations to learn English are often thwarted by their current

\footnotetext{
${ }^{3}$ Throughout the study, I refer to the participants and other members of their community using the term 'Latinx' because this term is generally preferred in academic publications. However, it is worth noting that the women themselves preferred the terms 'Latino' and 'Latina' to refer to themselves and others.
} 
life circumstances. I end by summarizing key observations about the ELLs in the study and making general recommendations to ESL programs for how to apply these observations.

\section{Chapter 2: Methodology}

\subsection{Research Questions}

This thesis seeks to address the following research questions which themselves are taken from a larger set of questions that loosely guided my research. I designed these questions to allow my findings to emerge from the data through loosely inductive processes.

1) In what authentic contexts, and with whom, do the women tend to use English rather than Spanish, and vice versa?

2) How do the women (most of whom speak little English) deal with situations where English is necessary? What linguistic, social, and other strategies do they use?

3) What are the women's goals related to learning English? What are their stated and unstated needs regarding English use in-context?

\subsection{Positionality}

I am a native English speaker who speaks Spanish fluently, though not with native-like proficiency. I learned Spanish as a young adult through university classes and studies/internships abroad in Mexico and Peru. I completed a BA in Latin American Studies and am therefore familiar with the generalities, and some specifics, of Mexican and Salvadoran history, politics, and culture. I also have approximately five years of experience teaching ESL to adult ELLs in the United States and abroad to university students in Peru as part of an internship, as well as teaching other languages, specifically Tagalog, to adult language learners in the United States. 
My interest in this topic of study came primarily though my experiences as an ESL teacher witnessing firsthand the difficulties CBLs faced in a program constructed around test-based analyses and the needs of their student visa-holding classmates.

\subsection{Theoretical Basis for the Ethnography}

I chose ethnographic research methods in designing and carrying out my study because these methods were well suited to addressing the processual nature of my research questions and providing me with in-depth data about the participants' authentic experiences and situated language contexts. I followed principles of participant observation, unstructured interviewing, focused observation, field note recording, and thick description as outlined by Spradley (1980), Packer (2018), Emerson, et. al. (1995), and Geertz (1973).

In analyzing the data I collected, I followed principles of qualitative analysis (Van Staa \& Evers, 2010), ethnographic data analysis (Spradley, 1980; LeCompte \& Schensul, 1999; Campbell Galman, 2013, 2019), and ethnographic discourse analysis (Celce-Murcia \& Olshtain, 2000; Tracy \& Mirivel, 2009; Manor-Binyamini, 2010; Gee, 2014). Applying the full rigor of Grounded Theory (GT -- see Glaser \& Strauss, 1967) was beyond the scope of my study; however, I did incorporate principles of GT and other 'thick analysis' (Van Staa \& Evers, 2010) into my work, most especially a rigorous inductive coding process as described below.

\subsection{Data Collection and Analysis}

My data collection relied most heavily on spending extensive time conducting participant observation with each of the women in the study. On average, I spent about three hours a week with each participant (introduced at length in the next section), observing and audio-recording 
her as she went about her daily routine and focusing specifically on her language use in both English and Spanish. Most of the observations occurred on weekdays, though I did conduct some weekend observations. Working within the limits of when it was reasonable to conduct them, observations took place at varied times in order to provide a good sense of the different parts of each woman's daily routines (a form of data source triangulation -- see Van Staa \& Evers, 2010). The number of weeks I spent observing each woman also varied according to her availability: I conducted 13 weeks of observations with Luciana; 10 weeks with Mariela; 7 weeks with Julissa, 6 weeks each with Ana and Rocío; and 4 weeks with Carmen. In ethnographic research, it is common to have widely differing times of observation since the purpose of the research is not to get a representative sample of each individual but to gain as much in-depth data as possible on as many people as possible so as to be able to recognize common, meaningful patterns that are occurring in these women's lives. I also conducted one formal, unstructured 30-minute interview with each of the participants where I asked her questions related to her routines, language use, personal goals, language goals, and perceptions of language learning. Finally, I conducted two formal ESL placement tests with each woman ${ }^{4}$ to assess her English ability: the MacMillan Straightforward Quick Placement Test ${ }^{5}$ and the LexTALE test (Lemhöfer \& Broersma, 2012). ${ }^{6}$ All of this together generated 116 hours of data, approximately 86 hours of it audio-recorded, and over 47,000 words of field notes.

\footnotetext{
${ }^{4}$ Unfortunately, due to forces outside my control related to the COVID-19 pandemic, I was unable to obtain the ESL placement test results of the two non-focal participants, Ana and Rocío. For the purposes of this thesis, I refer instead to what I observed and recorded about their levels of English proficiency.

${ }^{5}$ A copy of the Straightforward Quick Placement test questions are included in Appendix 2.

${ }^{6}$ The efficacy of the LexTALE test has been well documented for advanced ESL learners. However, after watching each of my participants apply massive amounts of guesswork to the test as they took it, I developed doubts about the test's efficacy for beginning learners. For this reason, I had the participants take a second, more traditionallystructured grammar- and vocabulary-based ESL placement test (the Straightforward Quick Placement Test). While no rigorous studies back up this second test's efficacy, it is produced by a very popular textbook company (MacMillan Publishers) and used in ESL programs to determine which level of curriculum materials an ESL student ought to be using.
} 
The observations were conducted in various settings the women frequented (e.g., home, church, stores and restaurants, doctor's and dentist's offices, their children's schools, social events, work, and English classes). Many of the observations included other individuals such as the women's spouses, children, friends, classmates, church congregation members, and others in the community.

Occasionally during the observations, I encountered pieces of conversation in Spanish that I could not fully understand. Where possible and appropriate, I asked the participants to clarify for me what was going on and explain vocabulary words I didn't know. Being able to revisit audio recordings of specific situations and listen to them again also helped me make sure I had a clear understanding of what I was observing.

As is common in ethnographic studies, especially those based in GT, my processes of data collection and analysis were iterative and, in some ways, concurrent. During the data collection phase, I documented events and conversations very closely through field notes and thick descriptions, the process of which, in and of itself, comprised the beginnings of analysis. Where I placed the most attention was influenced by my research questions: I paid special attention to conversations and linguistic interactions, both in English and Spanish. I listened for what the women talked about with whom, how they went about their interactions, and where each language did or did not come up and why.

I tracked patterns and looked for important themes as I went about data collection, a preliminary analysis that involved multiple rounds of analyzing the data. I discovered themes and patterns I hadn't necessarily expected to find, then returned to the data to see if there was 
sufficient evidence to support these themes. ${ }^{7}$ I was able to refine my study as it went along, making adjustments to my methods and routine to be sure I followed up on leads and corroborated themes I saw emerging. I also became aware as time went on of which women were most responsive and most likely to let me into their lives on a deep level; the three most responsive women became those I spent the most time with over the greatest number of weeks. I came to know all the women and their families well, and my observations and insights into their lives became much deeper than just witnessing their language use: participating with them in authentic contexts (e.g., linguistic, cultural, familial, etc.) was key to being able to produce thick descriptions of their experiences (see Geertz, 1973).

I conducted the interviews during the final stages of my data collection phase. I was able to ask them questions that related to their specific personal and language situations because of how well I knew them. One especially fruitful part of my analysis involved comparing what the women said about their language goals and experiences with what I actually witnessed during the participant observation. For instance, a major theme that emerged from the interviews was that the women almost universally expressed a desire to learn "everything" in English as though the language were one concrete entity and mastery of it were a binary on-off switch. However, observational data showed that the strategies the women used to engage in English in authentic contexts led to much more piecemeal and locally-oriented outcomes -- strategies and outcomes that will be detailed in later sections of this thesis.

As part of my analytical process I made inventories of the data, detailing where and when each observation took place (and which recordings went with it) and what notable events or

\footnotetext{
${ }^{7}$ Appendix 3 contains more details on the arguments I isolated, as well as various (though not exhaustive) examples from the data that support these arguments. I am only able to include a small number of these examples in the thesis itself due to length constraints.
} 
interactions happened in each observation. ${ }^{8}$ I then undertook an even more in-depth process of analysis, forming a series of concrete codes and sub-codes, ${ }^{9}$ based on the general inductive principles of GT and drawn from my preliminary analyses, to apply to the data in order to find patterns, track examples of the emerging themes, and discover new information. I then colorcoded specific instances and examples of my codes throughout my field notes. I also generated new codes, refining and sometimes changing existing codes, as I did this. I isolated some of the most productive pieces of data and either transcribed them to analyze them word-for-word or used the very detailed notes I had generated about them to analyze them closely. Doing this, I was able to isolate the linguistic and other phenomena I witnessed the women employing in specific contexts. Due to the sheer volume of data I collected, I transcribed only the interviews and selections from my audio-recorded data rather than attempting to transcribe all the data. The majority of my analysis relied on my detailed field notes rather than full transcriptions of audiorecordings.

After coding the data, I compiled information gleaned from coding with the arguments I had already developed in my previous analysis. I assembled examples to support each theme that had emerged from the data, then made decisions about what arguments to fully develop for the purposes of this thesis and which to leave for further analyses and future papers.

\footnotetext{
${ }^{8}$ My main data inventory is included in Appendix 4.

${ }^{9}$ An inventory of my codes and sub-codes (my "codebook") is found in Appendix 5. Due to IRB concerns, and to protect the privacy of my participants from those not authorized to conduct data analysis on this study, I did not include the coded field notes themselves.
} 


\section{Chapter 3: The Participants}

The focal participants in this ethnography consisted of four Salvadoran immigrant women (Luciana, Mariela, Julissa, and Carmen ${ }^{10}$ ) with limited English proficiency who live in Thurston, a mid-sized city in the western United States. Salvadorans in the US are currently at the center of a precarious political battle: due to the ongoing effects of El Salvador's civil war (1979-1992) and current gang wars, most Salvadorans in the US have Temporary Protected Status (TPS), a legal status offered to certain types of refugees that permits them to live and work legally in the US. The Trump administration, however, has made plans to remove El Salvador as a TPS-designated country in January 2021 (US Citizenship and Immigration Services, 2019). If this goes into effect, 320,000 Salvadoran immigrants in the US will lose their legal status. Concerns about the future of their legal status weighed heavily on the minds of the affected women and their families since all four women, as well as their husbands, migrated to the US for similar reasons: to escape economic instability resulting from the civil war. As one participant, Carmen, told me, life in the US requires continual sacrifices, but it is worth it to provide the children with a better life and opportunities.

To provide additional data, ethnographic observations also included a Mexican immigrant with high English proficiency (Ana) and a Mexican student visa holder with similar home responsibilities but a different focus than the other participants (Rocío). Though these women did not face the exact same pressures as the Salvadoran participants, they shared many of the same characteristics and community affiliations. These observations deepen and sometimes provide contrast to the data I collected with the core participants. The biggest difference between

\footnotetext{
${ }^{10}$ All names that appear in the study, including those of all participants, their friends and family members, the church they attend, and the city in which they live, are pseudonyms. (The names of smaller stores and businesses that could be identified have also been anonymized; I did not attempt to anonymize the names of large chains like Costco, Sam's Club, McDonald's, or Walmart.) An inventory of the (anonymized) names that appear in the study and how these relate to the participants is included in Appendix 6.
} 
Ana and the other participants was Ana's high level of English proficiency, while differences between Rocío and the other participants included Rocío’s amount of time in the US and reasons for coming, her focus and goals as a student visa holder, her high level of educational attainment, her socioeconomic background, and her attitudes and perceptions about learning English.

\subsection{Luciana}

Luciana (now 48) walked on foot from El Salvador to the US in 2001 when she was 29 years old. She was blessed, she says, to avoid being killed, kidnapped, or raped -- all common occurrences for migrants like her. Yet her travel was not without incident: during the 3,700-mile journey, her group ran out of food and water and all her toenails fell off due to walking so far. She narrowly escaped being kidnapped by a group of men but managed to complete the journey safely. Now she dreams of a happy life and a college education for her two younger children, Kimberly (12) and Oscar (10), and her four grandchildren, the children of her older daughter Abigail (26). She worries about the future, especially with the uncertain fate of TPS and the rampant violence in El Salvador should she have to return. She is also concerned by the challenges her children face in their underprivileged neighborhood and Title 1 school in Thurston.

Luciana is a leader in a local Latinx Pentacostal congregation called La Iglesia Cristiana Pentecostal. She occasionally helps her husband, Rodrigo, with his carpet-laying business, but she dislikes the heavy work despite telling Rodrigo she enjoys it "para animarlo" (to encourage him)). In El Salvador, she completed a few semesters of college and worked as a secretary. Someday she'd like to have a professional job here, but because of language and other barriers, 
she laments, solo puedes hacer tu propia profesión en tu propio país (you can only do your own profession in your own country).

Luciana scored $68.75 \%$ on the LexTALE test and 20/50 on the MacMillan Straightforward Quick Placement Test, placing her in the second-to-lowest level (Elementary) of the MacMillan scale. She says she knows very little English and would self-asses to the lowest level.

\subsection{Mariela}

In 2009, Mariela (now 35) left her three-year-old son, Eduardo, with her parents in El Salvador and migrated by plane to the US to join her husband, Paul, who had arrived five years earlier. In 2012, they were able to bring Eduardo (now 15) to join them. Today, Mariela and her family live in a modest home with a yard and a garden. They now have two more children, Christian (9) and Paulito (5), both born in the US, and a chihuahua whom Mariela loves to dress up in sweaters and tutus.

Mariela cleans houses part time for Latinx clients. Paul, like Luciana's husband Rodrigo, has his own carpet-laying business. Mariela didn't finish high school and is semi-literate in Spanish. Still, she attends community English classes and is determined to "esforzarse"(exert herself) even though, she says, her children and daily tasks make it hard for her to find time to study. Mariela is also very involved in La Iglesia Cristiana Pentecostal and spends hours cooking meals each week to give the homeless as part of her church's ministry. She also goes out with friends and loves traveling (mostly by car): she and her family go several times a year to relax and swim in Las Vegas or to visit family in nearby states. 
Mariela scored $58.75 \%$ on the LexTALE test and 14/50 on the MacMillan

Straightforward Quick Placement Test, placing her in the lowest level (Beginner) of the MacMillan scale. She describes herself as "knowing 20\% of English and missing the other $80 \% ”$.

\subsection{Julissa}

In 2004, at the age of 14, Julissa (now 29) migrated to the US from El Salvador alone and on foot. She set out to join her mother and sister, who had migrated to Texas many years before. (I pressed her for details on how she managed this, but she didn't tell me more.) After arriving, Julissa attended a US high school for approximately a year but dropped out at 15 when she became pregnant with her oldest son, David. "No me arrepiento de eso" (I don't regret it), she says, but she would like her children to get more education than she did. She says she would love to visit her many cousins in E1 Salvador someday, but she is afraid to go back for fear of gang violence. Today, Julissa lives in a small apartment in Thurston with her Salvadoran husband, Angel, and her children, David (13), Daniel (10), and Kevin (2). Angel works as a carpet cleaner, but for a Latinx business owner rather than for himself. Julissa makes and sells pupusas to friends and clients and resells clothing and shoes through the Facebook Marketplace. Like the other Salvadoran participants, she dedicates lots of time to serving in La Iglesia Cristiana Pentecostal. She loves reggaetón music and going out with friends, and she attends a Latinx Zumba class at least once a week at a local Catholic church.

Julissa scored $63.75 \%$ on the LexTALE test and 19/50 on the MacMillan Straightforward Quick Placement Test, placing her in the second-to-lowest level (Elementary) of the MacMillan 
scale. She says she can get by in many English situations but she struggles in longer conversations and avoids English when possible.

\subsection{Carmen}

Carmen (now 49), Luciana's sister-in-law, migrated from El Salvador to California in 1993 with her Salvadoran boyfriend. The couple broke up after arriving, but Carmen met and married another Salvadoran immigrant, Edgar. They now live in Thurston in a nice two-story home with their three American-born children: Aaron (23), Alexander (14), and Laura (11). Aaron works full time and attends the local public university. Both Carmen and her husband work long, arduous hours (including night shifts) at local factories. In her free time and on weekends, Carmen loves to organize parties and outings with Latinx friends. She, too, is very involved in La Iglesia Cristiana Pentecostal.

Carmen scored $63.75 \%$ on the LexTALE test and $8 / 50$ on the MacMillan Straightforward Quick Placement Test, placing her in the lowest level (Beginner) of the MacMillan scale. She says, "No puedo inglés, pero sí puedo defenderme" (I don't speak English, but I can get by).

\subsection{Ana}

In 1995, at the age of 14, Ana (now 38) migrated to the US from Michoacan, Mexico, and settled in Nevada with her family. She completed several years of American high school and was a dedicated student, but during her senior year she was the victim of a hit-and-run. She suffered some brain damage and accrued substantial medical bills; these two pressures together forced her to drop out of high school. She began working at a fast food restaurant and married 
her high school sweetheart, Francisco; they now live in a trailer home in Thurston with their six children. Francisco works in construction and Ana is a stay-at-home mother.

Like the other participants, Ana often runs errands or accompanies her children to appointments, but this is uniquely difficult for her: she has no car or driver's license due to a debilitating fear of driving which she relates to her accident. She relies on her "taxi driver" (a Salvadoran, the friend of a friend, whom she pays to drive her places) or on public transportation. Both of these methods of transportation make getting around difficult, and public transit can add four hours or more to a simple trip to the store.

Based on my observations of her and the English-language interactions I recorded with her, I estimate that Ana would place in a high-intermediate or low-advanced level on an ESL placement test.

\subsection{Rocío}

Rocío (43) came to the US from Sonora, Mexico a year and a half ago on a student visa with her husband, Manuel, and their four children. Unlike my other informants, Rocío came with the express purpose of learning English and getting a Master's degree in Computer Science from an American university. She already has a Bachelor's degree in Computer Science from a Mexican university. In Sonora, Manuel was a professor of Finance at a university; here he works as a janitor and also in the kitchen of a local taco shop. Rocío doesn't currently work and spends four to five hours per day attending ESL classes at a local for-profit English school for adults. The family attends an English-speaking church on Sundays, but, Rocío says, they still don't get much chance to practice English because so many of the congregation members speak Spanish. The family lives in a small basement apartment in Thurston. 
Based on my observations of her (including classroom-based observations) and the English-language interactions I recorded with her, I estimate that Rocío would place in a beginning level on an ESL placement test.

\section{Chapter 4: Daily Routine and Language Use -- Addressing Research Question 1}

Most notable in the women's routines was the importance of their involvement in a Latinx community, or enclave, where only Spanish was spoken. In this thesis, I define enclave as a concentrated group of ethnically, culturally, and linguistically similar individuals (often firstand second-generation immigrants) who build and participate in "economies [of] communication, information, consumption, and the labor market" that are different, and somewhat separate, from the host nation's mainstream society and economies (Chiswick \& Miller, 2005; p. 7). With an estimated Latinx population of 16\% (US Census Bureau), the Thurston area has a robust Latinx enclave, including social networks, concerts and events, businesses, churches, and more. All the women in the study actively participated in Thurston's Latinx community, and all the Salvadoran participants knew each other and were involved in the same church and social groups. While the women's participation in Spanish-language enclaves has likely prevented them from developing better English skills during their time in the US, it has also given them the scaffolding and support they needed (both culturally and linguistically) to "make it" in the US and build lives for themselves and their families.

Regarding the women's daily routines, all the women other than Carmen (who worked full time) spent large amounts of time at home on weekdays doing housework, attending to their young children, and driving their older children back and forth between school and activities. Many of their daytime hours were spent alone without much opportunity to interact with others, 
especially other adults. They also ran frequent errands around town, typically shopping at one or more grocery stores per week and sometimes at other stores. Occasionally, they dined at or ordered out from restaurants. All the women had memberships at Costco, Sam's Club, or both, and they tended to buy from some American establishments where English was sometimes required of them (Costco, Sam's Club, the beauty supply store, the dollar store, the grocery store, McDonald's, The Pizza Parlor) and some Latinx establishments (the Latinx market, a local Guatemalan restaurant, taco shops, Mexican juice bars). Based on my observations (see chart below), the women seemed to frequent American stores more often than American restaurants, in part likely because more English interaction was required at restaurants than stores. They also made rare trips to places like banks, doctor/dentist's offices, and the children's schools. The following table shows the total number of visits to various community locations I witnessed while accompanying the participants.

Table 1: Participant Visits to English-and Spanish-Speaking Venues

\begin{tabular}{|lc|}
\hline Type of Venue & $\begin{array}{c}\text { Number of Visits I } \\
\text { Participated In/Observed }\end{array}$ \\
American big box store & 9 \\
Latinx market & 2 \\
Latinx restaurant & 4 \\
American restaurant & 2 \\
Bank & 1 \\
Doctor/Dentist Visit & 4 \\
Elementary School & 1 \\
\hline
\end{tabular}

Occasionally, the women engaged in part-time work but generally only for a handful of hours per week. Mariela attended a few hours of community English classes per week; Rocío, the only participant for whom learning English was a primary commitment, attended English 
classes daily. During evenings and on weekends, the participants engaged with their church community and spent time with friends and family, either at home or on outings to various locations, typically Spanish-speaking ones (as described below) but sometimes others like museums or zoos.

As described in what follows, the women's daily participation in cultural/linguistic enclaves curtailed much of their immediate need for English as the majority of their authentic contexts were Spanish-speaking ones. Often entire days went by in the women's lives where no English interactions were necessary. However, situations did occasionally arise where English was needed, revealing the strategies the women employed (with mixed results) for getting by in English.

\subsection{Enclave Participation and Situations Where English Was Not Required}

The women's participation in cultural and linguistic enclaves was woven throughout every part of their lives. Here, I document the specific types of situations in the women's lives where only Spanish was required.

\subsubsection{Social Lives}

With a few exceptions (described later), all of the women's home, family, and social interactions were in Spanish. Among other things, I observed them participating in Spanishlanguage Zumba classes, going out for tacos or ice cream with friends, attending Latinx Christian rock concerts, and hosting parties for Latinx friends and family. Throughout all of these interactions, English was almost never necessary. Additionally, the women's social networks were tight-knit enough that social interactions happened in unplanned ways. I accompanied 
Mariela on two separate occasions when she unexpectedly encountered and chatted with Latinx friends while running errands. Of all the informants, only Mariela said she had any non-Spanishspeaking friends; she admitted, however, that her only one is the American husband of a Latinx friend. The women's social decisions perpetuated their participation in the enclave: all of those who married after arriving in the US (Luciana, Julissa, Carmen, and Ana) married Latinx husbands from their home countries (in this case, three from El Salvador and one from Mexico) whom they met through Latinx community connections.

\subsubsection{Latinx Stores, Restaurants, and Businesses}

In addition to sociality, the Latinx enclave provided the women with opportunities to accomplish many of their daily errands and routines, even without much knowledge of English. Latinx businesses (markets, restaurants, etc.) provided spaces for the women to navigate complex interactions entirely in Spanish. For example, I watched Mariela deftly navigate ordering the exact right type, cut, and amount of meat from a butcher at the Latinx Market. Another time I watched her craft a complex food order at a Guatemalan restaurant consisting of items not on the menu. Had these been American businesses, she would not have been able to accomplish either of these tasks.

\subsubsection{Church Participation}

The four Salvadoran women's participation in a Latinx Pentecostal church community (la Iglesia Cristiana Pentecostal) also provided them with various community contexts in which only Spanish was needed. In one interaction, I witnessed Carmen distributing sack lunches to a group of mostly white homeless people gathered at the back of the church -- a reversal of stereotypical roles in which white English speakers are in a position of power to "help" ELL 
refugees and immigrants. The last homeless woman to receive a sack lunch, a Native American (the only non-white in the homeless group), said "thank you" in English to Carmen; when she received no reply, she repeated it in heavily-accented Spanish: "gracias."

\subsubsection{Work and Employment}

The women and their husbands all had jobs that they acquired through Latinx connections and where they were able to mostly use Spanish, especially with their coworkers. This included the participants' part time work, such as Julissa's pupusa sales and Facebook Marketplace sales (all done in Spanish) and Mariela's house cleaning (with only Spanishspeaking clients).

\subsubsection{Family Interactions}

Finally, the enclave provided a space where the participants' children could learn about and maintain the culture and language of their parents, something almost all of the participants mentioned was important to them. The participants wanted their children to honor their Latinx heritage and be bilingual in English and Spanish -- an advantage that had already helped Aaron obtain a better, higher-paying job than the monolingual Americans at his company, Carmen proudly told me. Importantly, the women's participation in the Latinx community didn't limit the children's English abilities. Even though all the participants but Ana used only Spanish with their children and most of the children used only Spanish with their parents, all the children were entirely fluent in English and most were excelling in school and in other ways. Aaron was a university student with a good job; Eduardo and Alexander (the children of Mariela and Carmen) were high-achieving, honors-earning high school students on the road to college; Francisco Jr. (Ana's son) was engaged in extracurriculars and sports at his high school and would have been 
on the varsity soccer team if he had not broken his nose two days before tryouts; and I witnessed most of the children being consistently responsible, dependable, respectful, and helpful to their parents and siblings.

\subsubsection{Media Engagement}

My observations gave me insight into how the women managed the many hours they spent alone during the day: they engaged with Spanish-language media (including music, TV, and social media) unless there were children present who wanted to watch programming in English. It should be noted that the one exception to the Spanish-media-only norm is that Ana, who, as a proficient English speaker, loved to watch English TV by herself.

All of these observations lead to an important finding about the women's ESL need beyond the already-noted finding that in most of the women's daily contexts, the primary language being "done" was Spanish: the women had very few opportunities in their daily lives to utilize or practice English, even if they were studying it in school. As I discuss later, ESL programs should not assume that non-traditional ELLs' learning is happening in an Englishimmersive setting just because the ELLs are located in the US.

\subsection{Daily Routines in the Enclaves and Beyond: When and Where English Was Used}

Notwithstanding the pervasiveness of Spanish-speaking contexts in the women's lives, some situations consistently arose where situated English was needed. I document these in what follows. 


\subsubsection{American Establishments (Stores, Restaurants, Offices, Banks, and Schools)}

The need for English often arose in contexts where the women visited a mainstream American store, restaurant, doctor or dentist's office, or one of the children's schools. In some cases, the women were able to manage by using minimal English and applying clever communication strategies. In other cases, complex English interactions were required and all the women except Ana required a translator. I give details and examples of these types of situations later on in the thesis.

\subsubsection{Encountering English in Media}

As stated earlier, none of the women but Ana ever chose to engage in English media alone during my observations. However, the women spent considerable time observing English TV and movies (or at least having them play in the background) while their children engaged in media in the afternoons and evenings. Often, it was difficult to tell whether the women were paying attention to this English-language media or not. However, Luciana once changed a movie her children were watching (Mowgli) from the English to the Spanish setting partway through, implying that she wanted to be able to understand, too. I also witnessed occasional examples of children trying to get away with media that their parents would have disapproved of by playing it in English so the parents would not understand and then lying about the content when asked directly.

\subsubsection{Encountering English in Writing}

Encountering English in writing seemed to pose particular difficulties for the participants. Although I did hear of instances where participants experienced success with written English (e.g., Mariela said she passed her written English driver's license test -- on the seventh attempt), 
I observed many examples of participants either misunderstanding written English or encountering writing hurdles they couldn't surmount and asking for my help. The following are examples of problematic situations I observed my participants encounter with written English.

- In Sam's Club, Luciana asked me to help her figure out which case of almond milk was unsweetened because she could not understand the English labels.

- Rocío asked me to translate the cooking instructions on two packages of frozen vegetables.

- In Walmart, Mariela asked me to help her translate and compare the ingredients of different bottles of diet pills.

- I observed Rocío answering a phone call from "Scam Likely;” after the call was over, she told me she was confused because someone of this same name had called her repeatedly but every time she answered there was a different person on the line. I explained to her that "Scam Likely" is not a name and told her what the words mean; we laughed together.

- In Sam's Club, Luciana was trying to choose the right cut of pork. She asked me to translate the terms "bone in" and "pork butt." (Notably, I was only able to translate "pork butt" by looking it up online on my phone because I actually did not know know the English term myself.)

Beyond these practical examples, the participants tended to perceive reading and writing in English as an intimidating hurdle, and Julissa and Luciana both told me writing was their biggest weakness in English. This is especially notable given that several of the participants had little formal education having not finished high school and that Mariela was semi-literate, even in Spanish. 
As seen in the above data, the women had an immediate need for the types of practical English skills they could utilize in American establishments like stores. They also had a need for more skills in reading and writing, especially when it came to directions, instructions, and ingredients. Another important finding is that most of the women's English encounters happened in consistent and predictable ways and locations. ESL programs should take note that for a given non-traditional ELL or group of ELLs, there is a finite and manageable number of situations where the need for English is likely to arise.

\section{Chapter 5: Strategies for Getting By in English -- Addressing Research Question 2}

When situations such as those described above did arise where the women needed English, they were often able to get by using what little they had in combination with other forms of communication such as deixis (see Van Lier, 2002). On the other hand, sometimes the women's attempts at getting by failed and led to awkwardness, inconvenience, and other problems. In nearly situations, the womens' English strategies led to localized outcomes rather than broad fluency in the language.

What follows are the strategies the women employed when English became necessary.

\subsection{Minimizing English Use and Utilizing Formulas}

Two of the women's most common strategies involved minimizing their need to say or do much in English. I observed numerous instances of the women using each of the strategies mentioned below, sometimes successfully and sometimes unsuccessfully. 


\subsubsection{Minimization Strategy 1: Prefabricated Patterns}

The situations where the women did need to interact in English were often routine and/or brief enough that the women were able to get by using short, memorized formulas -- sometimes referred to in the literature as prefabricated patterns -- see Dornyei $(1995,1998)$. In most of the instances I observed of the women using prefabricated patterns, they were able to navigate the English situation successfully, especially when they combined them with other communication strategies such as deixis. The only failures occurred when a formulaic conversation suddenly took an unexpected turn and the women had to improvise in ways they weren't expecting.

I was often able to recognize when the women were employing a prefabrication by noting their speech patterns. The formulaic phrases tended to have no pauses between words and low articulation of syllable differences and were sometimes missing certain consonants or other phonemes, suggesting they had been memorized as a single entity. Also, when asked to repeat, clarify, or confirm what they meant, they tended to repeat the entire formula -- even when it was not pragmatically or semantically appropriate to do so (see the McDonald's example below).

The women were very conscious of their use of prefabricated patterns. In one instance, the business insurance example below, I asked Luciana to articulate how she navigated the situation, and she responded by describing how she had memorized enough formulas and pieces to get by in this routine interaction.

The following are examples of prefabricated patterns I watched the women utilize:

- "gimmeasmallcoffeeantwoburritos". Luciana utilized this formula at the McDonald's drive-thru when the voice through the speaker asked her what she wanted to order. When the 
voice then asked her to confirm by saying, so that was a small coffee and two burritos?, Luciana responded again with the complete formula.

- “scuse me”, “hammash” (how much) and "I hava question”. Mariela utilized these formulas in an interaction with two Walmart employees. Interestingly, as can be seen in the following transcript of the encounter, she was also able to navigate some unexpected things that arose during this interaction, mostly by utilizing formulas. It is also notable that Mariela's ability to communicate in this situation was enhanced, and her need to put together longer and more complex English sentences minimized, through use of deixis in addition to verbal language (her own deictic action when she gestured twice to the soda display as well as that of the employee who gestured to another worker and the second worker who gestured to the display case to confirm Mariela’s meaning).

(Mariela and I stand in a Walmart aisle looking at a display case of soda on sale. There is a price tag at the top of the display case, but Mariela says she wants to confirm the price.)

M: (taps employee on shoulder) 'scuse me, lady... hammash is? (gestures to soda case display)

E1: uh uh ask-- she might know (gestures to a different worker nearby, who is helping another customer)

M: uhh... (hesitates)

E1: in the yellow vest

M: oh okay, thank you (turns to the busy yellow-vested worker nearby. We wait for a long time.)

(to the worker helping the other customer) escuseme I hava question. sorry. 
(other worker is still busy and looks flustered by the interruption. She doesn't respond. We wait longer.)

(We wait longer. I point out another worker nearby hanging up clothing and suggest Mariela speak to her instead, but she declines because the worker is in the wrong department.)

M: (turns again to the worker helping a customer) hammash is...is...this.... (gestures again to soda display)

E2: that one? (gestures to display)

M: uh huh

E2: $\quad \$ 6.97$.

M: oh ok thank you

E2: $\quad$ yeah you're welcome

- "I need to maka payment" and "I hava new number". I observed Luciana successfully complete a phone call paying for her husband's business insurance. She started out the call by saying, "I need to maka payment." After the woman on the other end of the line responded, Luciana said, "I hava new number" before reading off her credit card number to the woman.

Use of formulas allowed the women to succeed in English situations that went beyond their usual speaking ability (such as the paying of business insurance) and allowed them to navigate some difficult English situations by themselves without translation or other help. 


\subsubsection{Prefabricated Patterns Gone Awry}

In most cases, it seems the formulas arose out of necessity: the women memorized a phrase or response they could utilize in a certain routine situation. In fact, Mariela told me this was her main English strategy: memorizing phrases and formulas immediately before going to an event that she guessed she might need while there. Even if the formula was slightly incorrect phonetically or was used in a pragmatically odd way, it was still fully understandable and served its purpose successfully. However, I witnessed occasional examples of formula formation "gone awry" that highlighted one possible limitation of the formulas: to the extent the women are unable to recognize the component vocabulary and grammatical pieces that make up the formulas, unintelligible results may occur. Here is one example:

\section{- "kiondemo"}

I was accompanying Mariela when she used this phrase at the Latinx Market after running into an old Latinx friend. After we finished conversing with the friend, Mariela commented to me that the woman used to be her children's teacher at their preschool, "kiondemo." Curious to know what she was talking about, I did an online search for preschool programs for low-income families and discovered that she was referring to the program Kids on the Move.

Use of prefabricated patterns and formulas was certainly the women's most ubiquitous and successful strategy for getting by in English, pointing to a need for ELLs to gain the skills necessary to identify and memorize helpful patterns based on specific situations as one strategy to achieving communication. However, as shown by Mariela's formula "gone awry," the 
weakness of memorizing formulas is that it doesn't necessarily lead the speaker to be able to decompose sounds or words for deeper learning.

\subsubsection{Minimization Strategy 2: One(ish)-Word Responses}

The other strategy I observed participants employing to minimize their use of English in interactions was to employ short, one-word (or close to one-word) responses to people's English comments and questions. Such responses included such things as yes, no, thank you, and hi. I observed these responses being used either effectively or ineffectively depending on whether the participant understood what was being asked of/spoken to them.

Sometimes the participants used short responses to give an accurate and appropriate, though non-elaborative, response to questions or comments they understood. Examples of this from the data include the following:

- I introduced Luciana to some of my English-speaking friends when we ran into them at Sam's Club. She responded to the introduction and conversation with a simple "Hi"

- A white man commented to Valery, the close friend of Julissa, that her toddler daughter was cute as we were getting ready to leave the taco shop. She replied with "thank you."

- While checking out with a cart full of groceries at Sam's Club, the cashier asked Luciana if she would be paying for all of this on one card. She replied with "no." The cashier appeared puzzled, since no further explanation was offered. Thinking she misunderstood his question, I turned to him and said actually yes, this will all be on one card. But Luciana said to me, in Spanish, no, actually it really is on two cards because the Iglesia is paying for the food for the pupusa fundraiser. I was impressed that she understood his question, and my response to the cashier, even when I myself was confused. 
On the other hand, the participants sometimes used short responses to mask the fact that they didn't fully understand the English question or comment and were unsure of how to proceed with the interaction -- a survival strategy referred to in the literature as "gratuitous concurrence" (Liberman, 1980). In this type of scenario, communication sometimes failed because the participant gave the "wrong" answer. Here is an example from the data:

- While checking out her daughter Kimberly from school, Luciana struggled to understand the secretary's questions. When the secretary asked her if Kimberly would be gone the whole day, she responded, "yes." A few minutes later, however, after the secretary realized that the purpose of checking Kimberly out was to take her to lunch, she asked Luciana if Kimberly would be coming back to school after lunch, and again Luciana said, "yes". Now confused by the contradiction, the secretary asked for clarification on whether Kimberly would be coming back or not. Luciana hesitated and again said, "yes". I finally responded for Luciana to clarify the situation, telling the secretary that Kimberly would, in fact, be back after lunch.

Use of short responses tended to break down most often when the women did not understand the broader context of the conversation they were engaged in, pointing to the need for the women to gain more strategies for decoding spoken English (and more practice in doing so) and the need for more situated ESL learning to give learners synchronous learning experiences in context. However, the data also point to how effective few English words can be in some situations. 


\subsection{Utilizing Translation Opportunities}

I witnessed various instances of the participants using their children to translate for them (both in person and on the phone) while doing such tasks as making dentist appointments, taking their children to appointments, and interacting with school officials at the children's schools. The participants also told me that their children translate for them in situations I did not have a chance to observe such as while ordering with the family at American restaurants.

In most of what I observed, utilizing children as translators worked fairly well. However, some of the children were more reluctant to help than others.

One situation arose in my observations where I became the translator myself. This took place at the bank where Luciana was trying to open some kind of business account. It was very hard to translate effectively for Luciana, and we finally decided to give up and come back another time when the Spanish-speaking loan officer was available.

Two things hindered my ability to translate effectively: I didn't have the necessary vocabulary to translate specific financial words to and from Spanish, and I didn't understand the complicated nature of what Luciana was trying to accomplish at the bank, so I couldn't adequately follow what she was saying or explain it to the loan officer. This is similar to what the participants' children sometimes experience while translating for their parents: a lack of complex adult vocabulary in one or both languages, combined with an inability to understand what is going on contextually, hampers their ability to be fully effective translators. This experience highlighted a type of situation where translation is not necessarily enough to get by. 


\subsection{Strategy-Free English (Natural Conversations)}

In rare cases, the women and their families engaged in "natural" or improvised English interactions without the aid of formulaic or memorized responses. Ana, the most proficient English speaker of the group, did this much more frequently than any of the other participants as her language skills made her more equipped to engage in non-scripted conversations. In situations where the other participants were prone to minimize interaction or rely on their children to translate (at the store, doctor's office, etc.), Ana took on the conversations herself and often even went beyond the necessary interaction to chat, socialize, and joke with English speakers around her. In this way, she was the only one of the women who participated socially in the English-speaking world.

The only participants besides Ana that I witnessed interacting in English without a script were Mariela on one occasion when a cashier at the dollar store briefly chatted with her, Julissa on one occasion at the beauty supply store enlisting the help of an employee to look for hair toner, and Luciana's husband, Rodrigo, on one occasion when a white contractor attempted to chat with him in English while he laid carpet. In this case, the interaction was strained as Rodrigo struggled to keep up.

Interactions with English-speaking children and grandchildren, including overhearing the children talk with each other and attempting to intervene, also provided the participants with opportunities to engage in non-scripted English, for better or for worse. I observed several instances where my participants were unable to understand what the children were saying, including a few where the children were speaking English on purpose to lock the parent out of their conversation and one where the child (David) was trying to speak directly to his mother (Julissa) about fixing a broken watch but was failing to communicate. 


\section{Chapter 6: Language Needs and the Participants' Stated Goals - Addressing Research Question 3}

I have described above how, through participation in Latinx enclaves and with strategies for minimizing English use, the women were able to navigate most of their daily interactions effectively. This brings up a valuable question: Is it necessary, therefore, for CBLs like these participants to learn more English than they already know? In addition to the rather important encounters that required either English skills or a translator (visits to the doctor and dentist, conversations with school representatives, etc.), this research suggests two reasons why English is important.

First, more English ability would ease the inconveniences the women currently experience due to limited English. While the women were generally able to get by without much knowledge of English, they were inconvenienced, sometimes in serious ways, while attempting to do so. For example, I accompanied Luciana to the bank for a second visit; she had already been to the bank earlier that day and was told to come back at a specific time when the one Spanish-speaking loan officer would be available. The Spanish speaker was not there when Luciana and I returned; apparently, Luciana had misunderstood the English instructions and returned at the exact time the bank attendant told her the Spanish speaker would not be there. Luciana ended up having to make three trips to the bank to complete a transaction that an English speaker could have done in one.

Second, more English ability would aid the women in fulfilling their long-term goals and dreams. When asked, all of the participants spoke of wanting to become fluent in English (except for Rocío, who had the more specific goal of wanting to become conversationally competent generally but only reach high-level fluency in her academic field), but they also talked about the difficulties of doing so: more important priorities like their children and their work keep them 
from putting in as much time and effort as they want to, the difficulties of learning English grammar and vocabulary hold them back even when they try their best to learn, etc. A common thread running through the participants' comments, as well as what I observed, was that a greater knowledge of English, while only moderately important for success in their current day-to-day interactions, had the potential to unlock long-term economic and social benefits for the women that were presently out of their reach.

\subsection{Long-Term Economic Benefits}

In many ways, the women were happy in their current lives and expressed pride in their children's achievements. In other ways, however, the stresses and difficulties of their situations weighed on them. Luciana, Ana, and Julissa lived near poverty. This was evident in their lessthan-ideal housing situations and in how they spoke about their husbands' jobs -- all three expressed stress and concern over how little their husbands made and/or how physically taxing the jobs were. Mariela and Carmen were better off, but their lives were stressful and required major sacrifices. Rocío and her husband also made many sacrifices to fulfil Rocío’s dream of getting a Master's degree in the US, but unlike the other participants, their difficulties were only temporary, lasting only as long as Rocío’s studies.

The women all expressed that knowing more English would help them overcome many of these problems. They noted that they would be able to get better jobs in the short run: Carmen and her husband could be promoted at the factory; Mariela could gain English-speaking housecleaning clients and grow her business. They also noted that in the long run, English would help them pursue their long-term goals: completing their GEDs, obtaining training to work in the 
medical field, being able to work in the profession they were qualified for in their home country, etc.

\subsection{Other Long-Term Benefits}

The women also spoke of the ways increasing their own English proficiency would help their children. If they had better jobs and more money, they would be able to live in nicer neighborhoods with more opportunities. For example, Luciana told me she would be in a better position to remove her children from living in close proximity to bad friends, drugs, and gangs, all of which were rampant in her underprivileged neighborhood.

Finally, the women wanted the expanded social opportunities they could gain through a greater knowledge of English. Mariela and Carmen in particular spoke of being able to “desenvolverse mas" (get more involved) with the English-speaking community, to express themselves, and to make more friends. The women discussed the importance of English to fulfilling this goal and to having a less burdensome life in the US.

Of course, language was not the only setback the women faced. Luciana told me that another setback to engaging in her actual career in the US was that the training requirements and certifications are so different in this country. Ana still did not have the time or resources to pursue the educational/career path she wanted to in spite of being a proficient English speaker already. Still, the women were quick to point to better English proficiency as one key component of moving forward with their goals. 


\section{Chapter 7: Conclusions and Recommendations for ESL Programs for CBLs}

As discussed above, the women in my study's participation in Spanish-speaking communities curtailed much of their need for English on a daily basis, as most of their authentic life contexts required only Spanish. When they did need to get by in English, this usually happened in limited, specific situations; often, the women were able to minimize the need to speak much English through effective strategy use, pointing to the validity of viewing language through a holistic lens that accounts for all forms of communication (not just purely linguistic ones) and meaning-making acts in situated contexts. Still, a better grasp of English would have the potential to give the women more independence in their current situations (something they affirmed they wanted) and unlock the door to future possibilities.

In this section, I summarize and discuss a handful of key observations from the study that ESL programs need to carefully attend to when helping CBLs. I also offer a few broad recommendations for such programs.

\subsection{Observation 1: Many CBLs have few opportunities to be immersed in English outside of school.}

A frequent assumption about ELLs in the US is that because they are living in a predominantly English-speaking society, opportunities to be immersed in and practice English are common in their daily lives. However, my findings uncovered an important paradox that ESL programs must take into account when attending to the needs of CBLs: the women's authentic experiences generated a need and motivation to learn English but provided very few opportunities to be immersed in it or even to practice it at all. This was true even for Rocío, notwithstanding the fact that learning English was her top priority in the US. 
One simple way to deal with this difficulty could be for ESL programs themselves to facilitate or create opportunities for learners to practice English outside of class (forming chat groups among students, facilitating lunch meetups, etc.). However, the women in my study had very limited time in their daily lives to dedicate to activities outside their normal responsibilities, so this plan could be only partially effective. A better solution could be to implement a flipped classroom model -- something that has already been shown to improve learning outcomes for adult ELLs (Han, 2015; Webb \& Doman, 2016). In this model, students spend their 'homework' time learning concepts at home through video or text. They then spend the majority of in-class time engaging with other students, practicing what they are learning, and asking question, thus getting at least some form of the immersive experience they lack outside the classroom.

An even more holistic solution, however, must take the deeply contextualized nature of language learning into account (see Van Lier, 2002, 2004, 2008b, 2011; Pennycook, 2010). ELLs like those in my study could greatly benefit from situated learning experiences (see Gee, 2004) that push the boundaries of the classroom walls and help them learn language and create meaning in authentic contexts and environments. One way to do this is by exploring resources that already exist in learners' spheres: finding ways to utilize English-speaking children as an asset to help their parents, for example, and utilizing existing social networks and community spaces like churches for meaningful English instruction and interactions.

\subsection{Observation 2: CBLs like the women in my study have a finite number of situations in which they use English on a regular basis.}

The approach of many community-based ESL programs and texts, including the program Mariela was enrolled in and the textbook she was using, is to give students tools for navigating a 
wide range of hypothetical, practical situations. In general, however, the women in my study's daily lives included only a small number of predicable, consistent situations where the need for English arose. By identifying and homing in on the actual situations where a specific group of ELLs consistently needs English, ESL programs can effectively target many practical needs while avoiding the teaching of unnecessary content. Of course, this suggestion only covers ELLs' practical, immediate needs -- something which, according to the findings of my study, is only one type of English instruction ELLs need or want in the long run. However, by targeting the specific, practical needs of a group of learners that arise from authentic, situated contexts, rather than attempting to prepare students for a huge range of possible situations that could hypothetically arise, programs could free up class time to be used in other, more productive ways.

\subsection{Observation 3: CBLs bring assets of many kinds to the table that ESL programs can take note of and capitalize on.}

Linguistic assets were one of the many types of assets the women in my study possessed. These included the various strategies the women already employed in navigating English situations (using prefabricated patterns, consciously memorizing phrases they thought they might need in advance of a situation, using in-context deixis and gestures to help create meaning, etc.). ESL programs can find ways to build up ELLs' existing strategies and resources, recognizing that even beginning ESL learners are not starting from square one and that many types of strategies and communication patterns are a part of "doing" language successfully.

Another of the womens' linguistic assets was the rich repertoire of language they already possessed in Spanish. When able to talk about whatever they wanted, my participants' interests 
and conversation topics were diverse and complex. Much of our conversation was rich in academic language features, including authoritative and persuasive voice, explicitness, decontextualization, abstraction and nominalization, etc. Recognizing CBLs' complex, academic skills and interests, even among those who do not have academically-related goals such as getting into an American university, is important for ELL programs seeking to find balance between practical and academic foci in their curricula and approaches.

Finally, the women possessed a diverse set of skills, interests, backgrounds, learning styles, educational experiences, views, and life experiences. A holistic program, recognizing that language learning goes beyond just cognitive processes and is inextricably connected to all of these things, must seek to take them into account in its approach. One way to do this is to employ democratic classroom principles, allowing the learners themselves to determine what topics, content, and even language features they want to cover in class (see Auerbach, 1992; Van Lier, 2008b).

\subsection{Limitations and Suggestions for Additional Studies}

While the participants in my study were, in some ways, representative of the larger Latinx community in Thurston, it is important not to extrapolate their experiences to those of all CBLs. In addition to being unique individuals whose experiences are inherently nongeneralizable, all the participants in my study were women, were married mothers with similar family structures including small children and/or adolescents at home, came from similar socioeconomic and cultural backgrounds (other than Rocío), had similar religious involvement, and were living in the same suburban community. Future studies could possibly gain diverse results from studying other Latinx immigrant populations, including men, LGBTQ+ individuals, 
college-age individuals (perhaps immigrant ELLs studying at community colleges), those from countries besides El Salvador and Mexico, those living in other settings (rural communities, inner city communities), and more. The goal of my study is not to propose sweeping generalities about Latinx CBLs so much as to illustrate the authentic experiences of one group of real-life CBLs and point to the impact this illustration can have on common assumptions about community-based language learning.

Future ethnographic studies could also narrow in on various aspects of participants' language experiences in ways I only broadly addressed in this thesis, such as focusing on their use of academic language, their experiences inside the ESL classroom, or their experiences doing homework outside the classroom.

\section{References}

Adult Education Interest Section Presentation (2017). ITESOL Conference, Aspen Grove, UT. 14 October.

Auerbach, E. R. (1986). "Competency-Based ESL: One Step Forward or Two Steps Back?". TESOL Quarterly, 20(3), 411-430.

Auerbach, E. R. (1992). “Making Meaning, Making Change. Participatory Curriculum Development for Adult ESL Literacy." Language in Education: Theory \& Practice 78. ERIC Publications.

Campbell Galman, S.C. (2013). The Good, the Bad, and the Data. Routledge.

Campbell Galman, S.C. (2019). Shane the Lone Ethnographer (2 $2^{\text {nd }}$ ed.). Rowman \& Littlefield. 
CASAS. (2017). Handbook for ESL/ELL Teachers: Focus on WIOA Title II Accountability: An Interactive Guide for New and Experienced Teachers: California Edition. CASAS. www.casas.org.

Celce-Murcia, M., \& Olshtain, E., (2000). Discourse and Content in Language Teaching: A Guide for Language Teachers. Cambridge University Press.

Chiswick, B.R., \& Miller, P. W. (2005). Do enclaves matter in immigrant adjustment?. City \& Community, 4(1), 5-35.

Colegrove, K. S. S. (2019). "Gracias por escucharnos": Listening and Learning from Latinx Immigrant Parents Through Video-Cued Ethnography. Anthropology \& Education Quarterly, 50(3), 291-312.

Donato, R. (1994). Collective scaffolding in second language learning. Vygotskian Approaches to Second Language Research, 33-56.

Donato, R., \& MacCormick, D. (1994). A sociocultural perspective on language learning strategies: The role of mediation. The Modern Language Journal, 78(4), 453-464.

Dörnyei, Z. (1995). On the teachability of communication strategies. TESOL quarterly, 29(1), 55-85.

Dörnyei, Z. (1998). Motivation in second and foreign language learning. Language teaching, $31(3), 117-135$.

Duff, P. A. (1995). An ethnography of communication in immersion classrooms in Hungary. Tesol Quarterly, 29(3), 505-537.

Duff, P. A. (2002). The discursive co-construction of knowledge, identity, and difference: An ethnography of communication in the high school mainstream. Applied Linguistics, 23(3), 289-322. 
Emerson, R.M., Fretz, R.I., \& Shaw, L.L. (1995). Writing Ethnographic Fieldnotes. The University of Chicago Press.

Firth, A., \& Wagner, J. P. (1997). On discourse, communication, and (some) fundamental concepts in SLA. The Modern Language Journal, 81, 285-300.

Freeman, D., \& Johnson, K. E. (1998). Reconceptualizing the knowledge-base of language teacher education. TESOL quarterly, 32(3), 397-417.

Gánem Gutiérrez, A. (2008). Microgenesis, method and object: A study of collaborative activity in a Spanish as a foreign language classroom. Applied Linguistics, 29(1), 120-148.

Gee, J. P. (2004). Situated Language and Learning: A Critique of Traditional Schooling. Psychology Press.

Gee, J.P. (2014). How to Do Discourse Analysis: A Toolkit. Routledge.

Geertz, Clifford (1973). “Thick Description: Toward an Interpretive Theory of Culture.” The Interpretation of Cultures: Selected Essays (pp. 3-30). Basic Books.

Glaser, B.G., \& Strauss, A.L. (1967). The Discovery of Grounded Theory: Strategies for Qualitative Research. Aldine Transaction.

Gomberg-Muñoz, R. (2019). Labor and Legality: An Ethnography of a Mexican Immigrant Network. Oxford University Press.

Gumperz, J. J., \& Hymes, D. H. (Eds.). (1986). Directions in Sociolinguistics: The Ethnography of Communication. Oxford: Basil Blackwell.

Han, Y. J. (2015). Successfully flipping the ESL classroom for learner autonomy. NYS TESOL Journal, 2(1), 98-109.

Horton, M., \& Freire, P. (1990). We Make the Road by Walking: Conversations on Education and Social Change. Temple University Press. 
Khansir, A. A., \& Pakdel, F. (2014). Needs Analysis and Language Teaching. Language in India, 14(3).

Kramsch, C. (1993). Context and Culture in Language Teaching. Oxford University Press.

Kvam, D. S. (2017). Supporting Mexican immigrants' resettlement in the United States: An ethnography of communication approach to building allies' communication competence. Journal of Applied Communication Research, 45(1), 1-20.

Lantolf, J. P., \& Genung, P. (2002). I'd rather switch than fight: An activity-theoretic study of power, success, and failure in a foreign language classroom. In C. Kramsch (Ed.) Language Acquisition and Language Socialization: Ecological Perspectives (pp. 175196). Continuum.

Leather, J., \& Van Dam, J. (2003). Towards an ecology of language acquisition. In J. Leather \& J. Van Dam (Eds.) Ecology of Language Acquisition (pp. 1-29). Kluwer Academic Publishers.

LeComte, M.D. \& Schensul, J.J. (1999). Analyzing and Interpreting Ethnographic Data. Altamira Press.

Lemhöfer, K., \& Broersma, M. (2012). Introducing LexTALE: A quick and valid lexical test for advanced learners of English. Behavior research methods, 44(2), 325-343.

Liberman, K. (1980). Ambiguity and gratuitous concurrence in inter-cultural communication. Human Studies, 3(1), 65-85.

MacSwan, J. (2020). Academic English as standard language ideology: A renewed research agenda for asset-based language education. Language Teaching Research, 24(1), 28-36.

Manor-Binyamini, I. (2011). A model of ethnographic discourse analysis for an interdisciplinary team. Journal of Pragmatics, 43(7), 1997-2011. 
Margolis, M. L. (1993). Little Brazil: An Ethnography of Brazilian Immigrants in New York City. Princeton University Press.

Marshall, H. (2000). Avoid wrecked heads with magic and machinery: strategies for surviving the coding phase of qualitative research. Paper for the Annual Conference of the Australian Sociological Association.

Monzó, L. D. (2016). “They don't know anything!”: Latinx immigrant students appropriating the oppressor's voice. Anthropology \& Education Quarterly, 47(2), 148-166.

National Center for Education Statistics. (n.d.) Nontraditional Undergraduates: Definitions and Data. https://nces.ed.gov/pubs/web/97578e.asp

Ohta, A. S. (1995). Applying sociocultural theory to an analysis of learner discourse: Learnerlearner collaborative interaction in the zone of proximal development. Issues in Applied Linguistics, 6(2), 93-121.

Packer, M. (2018). The Science of Qualitative Research ( $2^{\text {nd }}$ Ed.). Cambridge University Press. Pennycook, A. (2000). "The social politics and the cultural politics of language classrooms." Bilingual Education and Bilingualism, 89-103.

Pennycook, A. (2010). Language as a Local Practice. Routledge.

Richards J.C., \& Rodgers T.S. (1986). “Approaches and Methods in Language Teaching.” Journal of Women's Health.

Saville-Troike, M. (2008). The Ethnography of Communication: An Introduction (Vol. 14). John Wiley \& Sons.

Spradley, J.P. (1980). Participant Observation. Holt, Rinehart, and Winston.

Swain, M., \& Watanabe, Y. (2012). Languaging: Collaborative dialogue as a source of second language learning. The encyclopedia of applied linguistics, 1-8. 
Tracy, K., \& Mirivel, J.C. (2009). Discourse Analysis: The practice and practical value of taping, transcribing, and analyzing talk. In L.R. Frey \& K.N. Cissna (Eds.) Routledge Handbook of Applied Communication Research (pp. 193-218). Routledge.

United States Census Bureau. (2018, July 1). “Quick Facts.” United States Census Bureau. $<$ https://www.census.gov/quickfacts/>

US Citizenship and Immigration Services. (2019, November 18). "Update on Ramos v. Nielsen." Department of Homeland Security. <https://www.uscis.gov/update-ramos-v-nielsen> Van Lier, L. (2002). An ecological-semiotic perspective on language and linguistics. In C. Kramsch (Ed.) Language Acquisition and Language Socialization: Ecological Perspectives (pp. 140-164). Continuum.

Van Lier, L. (2004). The semiotics and ecology of language learning. Utbildning \& Demokrati, 13(3), 79-103.

Van Lier, L. (2008a). Ecological-semiotic perspectives on educational linguistics. In B. Spolsky \& F.M. Hult (Eds.) The Handbook of Educational Linguistics (pp. 596-605). Blackwell Publishing

Van Lier, L. (2008b). Agency in the classroom. Sociocultural Theory and the Teaching of Second Languages, 163, 186.

Van Lier, L. (2011). Language learning: An ecological-semiotic approach. In E. Hinkel (Ed.) Handbook of Research in Second-Language Teaching and Learning, Vol. 2 (pp. 383394). Routledge.

Van Staa, A., \& Evers, J. (2010). 'Thick analysis': strategie om de kwaliteit van kwalitatieve data-analyse te verhogen. $K W A L O N: 43(1), 5-12$. 
Warriner, D. S. (2007). "It's just the nature of the beast": Re-imagining the literacies of schooling in adult ESL education. Linguistics and Education, 18(3-4), 305-324.

Webb, M., \& Doman, E. (2016). Does the Flipped Classroom Lead to Increased Gains on Learning Outcomes in ESL/EFL Contexts?. CATESOL Journal, 28(1), 39-67.

West, R. (1994). "Needs analysis in language teaching.” Language Teaching, 27(1), 1-19. 


\section{Appendices}

\section{Appendix 1: Criteria for Defining a Community-Based ELL (Based on NCES standards for defining non-traditional students)}

1) They must be at least 25 years old, since this is the age the NCES typically uses in its characterization of non-traditional students and since age is most often considered "the defining characteristic of [the non-traditional student] population" (nces.ed.gov).

2) They must also fit at least one (preferably several) more of the NCES's descriptors for non-traditional students (hold a full-time job, care for children or other dependents, be financially independent of family or sponsors, do not have a high school diploma).

3) They must be long-term community members (rather than individuals with plans to stay in the US only for school) and non-holders of student visas.

4) Their primary plans and goals for the future must not include seeking further higher education in a graduate or undergraduate program.

5) They must have desires and goals to learn/improve their English but need not be currently enrolled in a formal language program. 


\section{Appendix 2: MacMillan Straightforward Quick Placement Test}

\section{Straightforward Quick Placement \& Diagnostic test}

The Straightforward Quick Placement \& Diagnostic test has been designed to help you decide which of the five levels of the Straightforward series is the most appropriate for you.

The Straightforward test has 50 questions, each worth one point. The first 40 are grammar questions and the final 10 are vocabulary questions. To decide your level, use the conversion chart below. Please note that these bandings are a guide.

\begin{tabular}{|l|l|}
\hline \multicolumn{1}{|c|}{ Total score } & \multicolumn{1}{c|}{ Level } \\
\hline $0-15$ & Beginner \\
\hline $16-24$ & Elementary \\
\hline $25-32$ & Pre-intermediate \\
\hline $33-39$ & Intermediate \\
\hline $40-45$ & Upper Intermediate \\
\hline $46-50$ & Advanced \\
\hline
\end{tabular}

This test can also be used to diagnose grammar that you need clarification on. Please consult the relevant level and unit of the course for more information.

\section{Grammar}

1. I from France.

Beginner Unit 1
a) is
b) are
c) am
d) be

2. This is my friend. name is Peter. 

a) $\mathrm{Her}$
b) Our
c) Yours
d) His

3. Mike is

Beginner Unit 4
a) my sister's friend
b) friend my sister
c) friend from my sister
d) my sister friend's

4. My brother is artist.

\section{Beginner Unit 2 / Elementary Basics 2}
a) the
b) an
c) $\mathrm{a}$
d) $\downarrow$

5. 20 desks in the classroom.

Beginner Unit 7 / Elementary Unit 3
a) This is
b) There is
c) They are
d) There are

6. Paul romantic films.

Beginner Unit 5
a) likes not
b) don't like
c) doesn't like
d) isn't likes

7. Sorry, I can't talk. I right now. 

a) driving
b) 'm driving
c) drives
d) drive

8. She at school last week.

Beginner Unit 8 / Elementary Unit 5
a) didn't be
b) weren't
c) wasn't
d) isn't

9. I the film last night.
a) like
b) likes
c) liking
d) liked

10. a piece of cake? No, thank you.

\section{Elementary Unit 1}
a) Do you like
b) Would you like
c) Want you
d) Are you like

11. The living room is than the bedroom.

\section{Unit 6}
a) more big
b) more bigger
c) biggest
d) bigger

12. The car is very old. We're going a new car soon. 

a) to buy
b) buying
c) to will buy
d) buy

13. Jane is a vegetarian. She meat.

\section{Beginner Unit 6 / Elementary}

\section{Unit 4}
a) sometimes eats
b) never eats
c) often eats
d) usually eats

e) There aren't buses late in the evening. Elementary Unit 3 / Pre-int Unit 3

f) some

g) any

h) no

i) $\mathrm{a}$

14. The car park is to the restaurant.

Elementary Unit 3 / Pre-int

Unit 3
a) next
b) opposite
c) behind
d) in front

15. Sue shopping every day. 


\section{Unit 4}
a) is going
b) go
c) going
d) goes

16. They in the park when it started to rain heavily.
a) walked
b) were walking
c) were walk
d) are walking

17. seen fireworks before?

Pre-intermediate Unit 7 / Intermediate Unit 2
a) Did you ever
b) Are you ever
c) Have you ever
d) Do you ever

18. We've been friends many years. Pre-intermediate Unit 10 /

Intermediate Unit 2
a) since
b) from
c) during
d) for

19. You pay for the tickets. They're free.

Intermediate Unit 3

a) have to 

b) don't have
c) don't need to
d) doesn't have to

20. Jeff was ill last week and he go out. Pre-intermediate Unit 11
a) needn't
b) can't
c) mustn't
d) couldn't

21. These are the photos I took on holiday. Pre-intermediate Unit 12
a) which
b) who
c) what
d) where

22. We'll stay at home if it this afternoon. Pre-intermediate Unit 8
a) raining
b) rains
c) will rain
d) rain

23. He doesn't smoke now, but he a lot when he was young.
a) has smoked
b) smokes
c) used to smoke
d) was smoked 
24. Mark plays football anyone else I know.
a) more good than
b) as better as
c) best than
d) better than

25. I promise I you as soon as l've finished this cleaning. Pre-intermediate

Unit 5 / Intermediate Unit 6
a) will help
b) am helping
c) going to help
d) have helped

26. This town by lots of tourists during the summer.
a) visits
b) visited
c) is visiting
d) is visited

27. He said that his friends to speak to him after they lost the football match.

Intermediate Unit 12 / Upper-intermediate Unit 10
a) not want
b) weren't
c) didn't want
d) aren't wanting 
28. How about to the cinema tonight?

\section{Pre-intermediate Unit 4}
a) going
b) go
c) to go
d) for going

29. Excuse me, can you me the way to the station, please?

Pre-intermediate Unit 3
a) give
b) take
c) tell
d) say

30. I wasn't interested in the performance very much.
a) I didn't, too.
b) Neither was I.
c) Nor I did.
d) So I wasn't.

31. Take a warm coat, you might get very cold outside.

\section{Upper Intermediate Unit 4}
a) otherwise
b) in case
c) so that
d) in order to

32. this great book and I can't wait to see how it ends. 
Intermediate Unit 7 / Upper Intermediate Unit 4
a) I don't read
b) I've read
c) I've been reading
d) I read

33. What I like more than anything else at weekends.

\section{Upper Intermediate Unit 1}
a) playing golf
b) to play golf
C) is playing golf
d) is play golf

34. She for her cat for two days when she finally found it in the garage.

Upper Intermediate Unit 5
a) looked
b) had been looked
c) had been looking
d) were looking

35. We won't catch the plane we leave home now! Please hurry up!

\section{Upper Intermediate Unit 6}
a) if
b) providing that
c) except
d) unless

36. If I hadn't replied to your email, I here with you now. 

a) can't be
b) wouldn't be
c) won't be
d) haven't been

37. Do you think you with my mobile phone soon? I need to make a call.

Upper Intermediate Unit 7
a) finish
b) are finishing
c) will have finished
d) are finished

38. I don't remember mentioning dinner together tonight.

Upper Intermediate Unit 10
a) go for
b) you going to
c) to go for
d) going for

39. Was it Captain Cook New Zealand?

Upper Intermediate Unit 12
a) who discovered
b) discovered
c) that discover
d) who was discovering

\section{Vocabulary}

40. You may not like the cold weather here, but you'll have to , I'm afraid.
a) tell it off 

b) sort itself out
c) put up with it
d) put it off

41. It's cold so you should on a warm jacket.
a) put
b) wear
c) dress
d) take

42. Paul will look our dogs while we're on holiday.
a) at
b) for
c) into
d) after

43. She a lot of her free time reading.
a) does
b) spends
c) has
d) makes

44. Hello, this is Simon. Could I to Jane, please?
a) say
b) tell
c) call
d) speak

45. They're coming to our house Saturday.
a) in
b) at
c) on
d) with

46. I think it's very easy to debt these days.
a) go into
b) become
c) go down to 
d) get into

47. Come on! Quick! Let's get
a) highlight
b) cracking
c) massive
d) with immediate effect

48. I phoned her I heard the news.
a) minute
b) during
c) by the time
d) the moment

49. I feel very . I'm going to go to bed!
a) nap
b) asleep
c) sleepy
d) sleeper 


\section{Appendix 3: Arguments/Themes and Supporting Evidences:}

1) The women were all participants in Latinx cultural and linguistic enclaves; their enclave connection wove through every part of their lives, with various results:

1a) Tracking enclave participation -- evidences from the data:

- All four women who married while in the US married husbands from their home countries (three Salvadorans and one Mexican) who they met through enclave connections (Julissa - Angel, Luciana - Rodrigo, Carmen - Edgar, Ana - Francisco)

- Media use: Luciana watches predicaciónes (sermons) on YouTube when she is alone at home; Julissa watches Spanish-language music videos and TV programs like the Latin American Music Awards; Mariela and Julissa spend time browsing Spanish memes and inspirational quotes on social media; All participants play Spanish-language music in the car and at home; Ana participates in online chat and gaming communities, all in Spanish. - Friend interactions: Mariela and Ana chat with friends on phone for hours on mulitple occasions; Julissa and Mariela have coffee together at least once per week; Carmen, Julissa, and Mariela go out with Latinx friends and family to eat, or invite them over for parties; etc.

- Jobs: All husbands work in jobs they got through the Latinx enclave (carpet laying, construction, janitorial work, taco shop server) except Edgar, who works at a factory but speaks primarily Spanish with his coworkers. Women who have their own part-time jobs (Julissa, Mariela) also work within the Latinx community: reselling through the Spanishspeaking FB Marketplace; making and selling pupusas to Latinx neighbors and friends; cleaning houses for Latinx individuals, etc.

-(Other evidences under section about where English was never needed/Spanish always used)

1b) The women find a lot of solace, connection, and community in their enclaves (in the form of personal and family friendships, spiritual connections through their church(es), connections to the foods and other things from their home countries, connections to Spanish resources and places (like even the store) where they can function independently, etc.) (Other example: Ana's kids are enrolled in Latinos in Action and they find it helpful).

1c) Situations where the participants rarely or never need English: at home (except when their kids are speaking English, to each other or to them, and they can't understand. They also watch some movies/TV in English, mostly with their kids -- except Ana, who watches lots of English TV herself, especially shows about true crime and serial killers -- and some in Spanish.); at church (except on rare occasions like Carmen trying to tell the homeless to come get their food); with their friends or acquaintances -- on outings, hanging out, or going to things like Zumba or to Latinx music concerts; with their own clients (but their husbands tend to run into English-speaking clients and that's stressful for them); within other aspects of the Latinx community, like participating in Spanish-speaking online gaming communities or chat groups (Ana especially), social media, Latinx multi-level marketing schemes, etc; at many of the Latinx 
stores and restaurants they frequent, like the Latin Market, the Juguería, the Pupusería, the Guatemalan cafe, taco shop, etc..

Some concrete instances in the data where English was not needed:

- Luciana orders tacos at the taco shop (interstingly, the server behind the counter was white, but seemed fluent in Spanish and completed the interaction with her in Spanish) - Mariela and Julissa order at the taco shop

- Ana orders at the Pizza Parlor (interestingly, the server behind the counter was Latino)

- Mariela is able to use Spanish at the front desk of the dentists' office because the receptionist is Latina

- At the eye doctor, Ana discovers that the receptionist speaks Spanish (though she's white) and conversed with her in it part of the time

- Mariela puts together a complex order on the phone from the Guatemalan cafe consisting of items that don't exist on the menu

- Mariela deftly crafts a complex order at the meat counter at the Mexican market, describing the exact cut, type, weight, etc. she wants.

- Mariela completes transactions with cashiers at the Mexican market on two occasions

- Mariela orders from the Juguería (Mexican juice bar)

- All the participants interact in Spanish at church -- including during the service, when they visit mid-week to serve food for the homeless, etc.)

- Participants (Luciana \& Julissa) participate in a pupusa and garage sale-style fundraiser with Latinx church members and other Latinx people in someone's driveway for several

hours on a Saturday morning, cooking and selling their own pupusas

- Julissa and friend Valery attend Zumba classes at least once per week with other Latinas - teacher is Latina and everything is in Spanish. After class, teacher weighs all the dancers, measures various body parts with a tape measure, and talks to the about their fitness goals.

- (Catholic church has everything bilingual)

- Carmen and Luciana travel to another nearby city to attend a Christian rock concert by a Latinx, Spanish-speaking band

- Most interactions with kids (Rocío's kids always speak to her, and each other, in Spanish; Mariela's kids always speak Spanish with her but sometimes use English with each other; Luciana and Julissa's kids primarily speak to them in Spanish but not always; both parents always respond in Spanish; Ana uses a mixture of Spanish and English with kids).

1d) Enclave participation does not hold back children from English fluency. All the kids are fluent in English, whether or not the kids were born in the US or not (all but Abigail and Eduardo were). It is notable, though, that the kids don't have all vocabulary words in both languages (typical of the process of growing up bilingual -- my conversation with Christian where he struggled to come up with the word "blender" in English or my converstion with Kimberly where she struggled to come up with how to say "broth" in Spanish, are prime examples of this). Some of the kids appear to have some American friends (Eduardo especially) but many do not (Luciana's kids? definitely Abigail. Rocío’s kids. Julissa's kids? Ana's teenagers at least) (their friends are other Latinx kids, first and second generation). Having Latinx friends does not hold 
the kids back from learning English. The kids' friend groups do influence them in the other goals their parents have for them, though, for better and for worse (not based on whether or not the friends are Latinx but instead on other factors): Luciana's kids have (or have had) bad friends who pull them down (the poster child of this being Abigail, who married her deadbeat high school boyfriend and didn't go to college like Luciana hoped she would). Another example: Luciana commenting to me about how Kimberly's one friend is a bad infuence; fighting with Kimbery after she lied to her about what she and the friend were doing. (And of course Julissa herself, whose high school pregnancy curtailed a lot of her life goals.) Eduardo seems to have good friends (Latinx and white) who are nice kids and good students like him. (Example: Listening to him talk about his friends, supporting his friends in school plays, visiting the mall with his friends after school; looking at pics of his friends with him on his phone) Mariela's kids have nice (Latinx) church friends. Luciana's kids, in addition to their sketchy friends, are friends with Carmen's kids (their cousins), and as per my observations they are much better behaved at Carmen's house with her kids than they are at their own house. Luciana's kids also have church friends. Mariela and Julissa's kids are friends with each other. At least some of Rocío's kids (Rafael in particular) have sketchy friends (examples: punk kid in kitchen, fistfight at school while Rocío and I waited in the car) and get in fights at school.

\section{1e) The participants care about having their kids preserve their Latinx culture and} national identities. Examples of this include everything from valuing speaking Spanish with their kids (and expressing sadness over some of their kids/grandkids losing or not having Spanish):

- Luciana talking (multiple times) about the senselessness of her grandkids not speaking Spanish

- Luciana looking on sadly as I joke with Lucy, Maxine, and Amanda in English and asking what we're talking about (on more than one occasion)

- Ana talking about how she chooses to cook traditional rather than Americanized meals for her kids so they can preserve this part of her heritage (and watching her cook chiles rellenos, other Mexican foods).

- Rodrigo recounting conversation he had with Kimberly about her being Salvadoran in addition to American

- Mariela telling her younger kids they were born in El Salvador (even though they were born in Thurston) so they would feel more connected to El Salvador.

2) In the limited situations where the need for English did arise, the women employed various communication strategies to "get by," even with limited language skills. This points to the idea, taken from the Vygotskian theoretical traditions of Language Ecology, Activity Theory, and Sociocultural Theory, that language is something we $d o$, not just something we know, and that all forms of communication that contribute to the making of meaning count as success in language (deixis, gesture, formualic expression, etc.).

Strategies included avoiding speaking where possible, use of prefabricated patterns, deixis and gesturing, use of short, one-word responses to minimize interaction, utilizing translation opportunities. 
2a) Situations where the need for English consistently arises: at restaurants and stores where English is the norm (McDonald's and other restaurants; Sam's Club and WalMart); doing things like paying bills on the phone; at the bank; at school with their kids; at regular doctor's offices (as opposed to low-income ones), at cultural events that are not Latinx (really only a thing for Rocío because the others are not participants in this community -- at plays, festivals, concerts, social functions in the English-speaking community).

2b) Avoiding speaking at all -- examples from the data:

Of successes:

- Luciana going through Sam's Club checkout without interacting at all with cashier

- Julissa -- similar experience with cashier at Sam's Club

- Manuel talking about how he minimizes having to interact with customers at the hotel where he is a janitor

Of failures:

- Awkward non-responses to the sample ladies at Sam's - Luciana

2c) Prefabricated Patterns -- examples from the data:

Of successes:

- McDonald"'s "gimmeasmallcoffeeanwtoburritos" - Luciana

- Walmart "Hey hammash" and "I hava question" - Mariela (also example of deixis)

- Camp Williams "Room Service" - Armando

- "I need to make a payment" and "I hava new number" - Luciana

Of failures:

- "kiondemo" - Mariela

- "belasedasai" - Mariela

- "Brali" - Mariela

2d) One-word responses -- examples from the data:

Of successes:

- School - short answers (yes, no), "Can I check out Kimberly?" "I don'know" - Luciana

- "Hi" to my ward friends in Sam's - Luciana

- Valery says "thank you" to guy who comments on cute kid - Valery (Julissa)

Of failures: 
- Luciana potentially not understanding school lady's question about teacher's name, then getting confused and giving her contradictory yes/no answers about whether she's bringing Kimberly back after lunch, then she's confused about what lady tells her about Kimberly's sign-in - Luciana

2e) Utilizing translation opportunities -- examples from the data:

Of successes:

- Eduardo translates phone call about changing the dentist thing - Mariela

- Eduardo translates conversations with actual dental assistants - Mariela

Of failures:

- I translate the conversation with the loan officer at the bank, but it's patchy and sketchy, both because of my lack of Spanish vocab and because I don't really understand the situation or what Luciana is wanting to do (73) - Luciana

2f) Natural, unscripted interctions -- examples from the data:

Of successes (*note that almost all of these come from Ana, who is the only one proficient in English):

- Success in rather complex interaction with Walmart yellowvests beyond formula Mariela

- Navigating front desk and chatting with front desk lady at ENT - Ana

- Engaging with PA - Ana (BUT HE IS WEIRD ABOUT UNDERSTANDING HER)

- "hey, do you want lunch?" - Carmen

- Navigating front desk at ENT again - Ana

- Navigating PA again - Ana

- Navigtating front desk and chatting at eye doctor - Ana

- Navigating conversation with eye doctor -- many, many questions - Ana

- Talking with glasses guy (other than CHIP fail) - Ana

- Participating in jokes and cameraderie with me and the glasses people - Ana

- Cashiers ask if everything is on one card and she navigates this when I fail - Luciana

- Successful toner and cash register interactions at beauty supply store - Julissa

- Mariela successfully chats (briefly) with chatty dollar store attendant - Mariela

(w/ kids):

- Seems to be able to follow my English conversation with David, and can give me any English word if I need it and ask for it specificially in Spanish - Julissa 
- Understands Oscar asking her why she's wearing a snow hat in English, and talking to her about "yo quiero three hot dogs" in Spanglish (though she responds in Spanish) Luciana

- Understands Maxine's “my deedee hurts" - Luciana

Of failures:

- Changes Mowgli from English to Spanish setting after few mins - Luciana

- Luciana went to Sam's and the cashier asked her something unexpected - she had to have him repeat it because she was confused. - Luciana

- Rodrigo is struggling to carry on conversation with contractor at his work - Luciana

- Luciana went back to the bank at the exact time the guy must have told her NOT to come back - Luciana

(w/ kids):

- Struggles to understand David trying to explain how he wants her to change or fix smartwatch - Julissa

- Seems wistful as she watches me interact effortlessly with Lucy in English, I try to steer the conversation back into Spanish and do some translation - Luciana

- I told you not to use words like that! - Luciana

- Luciana asks what we're saying when I try to scare Kimberly into eating veggies -

Luciana

2g) Difficulties when encountering English in writing -- Examples from the data:

- Almond milk incident (9) - Luciana

- Asking me to translate the instructions on the cheesy veggies and other package (41) Rocío

- Luciana is confused about the "check-in" part of the school form -- is or for her firma?” (48) - Luciana (BUT the writing was also in Spanish, so language might not be only reason for confusion

- Difficulty writing "appoiment” (48) - Luciana

- CHIP debacle (50) - Ana

- diet pills incident (57) - Mariela

- Scam likely (57) - Rocío (BUT this is also where she uses Spanish to get out of the call)

- "Bone in" and "pork butt" (59) - Luciana (BUT I don't actually know what pork butt is either... so language isn't the only problem going on.)

- Estela Brali (Bradley) (64) - Mariela

3) All the participants (except Rocío, who doesn't actually fit the research criteria) have the goal of wanting to be "fluent" in English and wanting to be able to talk about "everything." They don't have the concept that language is a more complicated scale than just an on/off 
switch. Rocío, on the other hand, does -- she wants to be basically competent and then have indepth knowledge of vocab and grammar for her field (computer science).

Examples/Sources from the data:

- Each woman told me this in her interview

- Comes up in other conversatios throughout the data

4) Reasons for wanting to be fluent are consistent across the participants and include wanting more economic opportunities for themselves and their families, more opportunities to do jobs they actually want to do (that are less physically challenging, that fit their training and/or interests), more educational opportunities (including GEDs and some technical school or even college desires), and more opportunities to mix socially into scenes beyond their enclave (including being able to live in nicer neighborhoods -- this seems to be partly an economic goal and partly a social goal.). Also to rely less on their kids for English translation help. They also want to be able to communicate better with their kids but their main focus for being able to do this is getting their kids to be better at Spanish vs. getting their own English better.

Evidences of the data about perceptions of current situation, dreams of future, etc:

\section{Neg Perceptions of current situations}

- Luciana's husband doesn't make much money at his business, she tells me.

- Luciana has problems with her landlord

- Julissa used to have problems with her landlord at their old apartment

- Luciana ended up leaving her janitor job at a good company because she didn't have enough English to make it work. Now she doesn't have a job, which is a financial stress. - Ana's husband has to work crazy hours in construction. Sometimes the work is very hard, especially in the winter when it's cold. Sometimes he comes home with "burns," like sunburns but worse. Frostbite, she says.

- Ana is worried that if it ever got extremely cold here -- a polar vortex like the one in Chicago last year -- they could really struggle in their trailer, which is hard (and expensive) to heat adequately.

- Ana feels it's too late for her husband and her to have better lives -- the best they can do is help their kids have better lives and better jobs than the ones they have and have had. - Julissa on getting pregnant and dropping out of hs: "no me arrepiento de eso," but she sometimes does wish she had more education.

- Luciana expresses frustration over Rodrigo's job with the escaleras -- doing stairs is much detail and time but little actual square footage to show, so he's only making $\$ 250$ for the three days.

- Luciana expresses frustration/worry about Rodrigo's latest carpet job -- a huge 3-story house super far away and how he's struggling to pull it off by the deadline at the end of the week and he's totally shot.

- Rocío laments the differences between Mexico and the US and how they frustrate her: driving is scary and fast (she's used to small towns with slow traffic and small roads) (though she says that drivers are infinitely sketchier in Mexico than they are in the 
US), there are so many restrictive laws about how many kids you can pile into one car, there are fewer community activities going on in public spaces (fiestas, eventos culturales), how people here are less friendly, it's harder to find cultural events like operas...

- Manuel is stressed about his taco shop job because of how many people there are and how fast everything moves and how he sometimes messes up the orders. Also, if he's not on time (which he really makes sure to be), they quitarle his tips, which are like \$80-100 per week.

- Ana's husband wants her to get her driver's license so that she'll be free. But she can't because of her mortal fear of driving... and so she is stuck with an extremely

inconvenient, time-consuming debacle when it comes to getting herself and/or her kids to any of the many places they need to be.

- Mariela is extremely stressed about the high amount they have to pay in taxes as selfemployed people with her husband's business

\section{Pos Perceptions of current situations}

- Rocío and Manuel know they're in a much strugglier situation here than they were in in Mexico, especially Manuel with his career drop, but they talk about how when you know why you're making sacrifices, and they're for a worthy goal, they're not hard.

- Carmen is very proud of Aaron, who is both going to college and working at a good job that helps everyone out. She tells me about how he got an even higher-paying position at his work than a normal American would have because he's bilingual and has Spanish and how great that asset is.

- She also has kids in the prestigious charter school, which she is happy about and she's proud of them.

- Luciana's apartment is severely dilapidated

- Moving here away from her family enclave in Texas has been a really hard adjustment for Julissa

\section{Dreams of Future for self}

- Luciana would like to take up her own profession (being a secretary/office manager/ executive assistant) here, but her English is too limited and also there are too many regulations and stuff. You can only do your own profession in your own country, she tells me.

- Minimally, Luciana would like for herself (and husband) to get jobs that require less physical exertion and are less exhausting than manual stuff like carpet laying. These are the jobs she would like English to unlock.

- Ana has always wanted to go into graphic art (2x) she says. But the tuition was too much money, so she didn't do it. Now she has no time. Maybe she can do it someday, but first she needs to get her GED, which she would really like to do. Now, though, instead of graphic art, she'd choose a shorter, easier program post-GED that leads directly to a job -- like cosmetology or hair school.

- Ana's car accident really affected her dreams and plans (and kept her from graduating high school, though she loved studying). 
- In the short run, Rocío would love to start her own online business. But she explains the complications of trying to do that here and earn money through it when she can't legally work.

- In the long run, Rocío wants to get her Master's in CS -- she wants to do it here and not in Mexico because the US is ahead on the cutting edge of the technology (Mexico always like 10 years behind, she says). Then she and Manuel want to go to China to immerse themselves and their kids in Mandarin.

Backgrounds before immigrating/Reasons for immigrating:

- Luciana: Has both fond and traumatizing memories of her life in El Salvador. Fond mems include her college years (though school was also too stressful for her), living in a dorm with roommates, and her job as an office manager. Neg memories include watching her sister accidentally cut off her finger and (potentially) seeing a neighbor get murdered outside her door -- and then witnessing the trial and everything of the murderer. She's worried about the violence and extortion going on there now, and worried that Oscar could get conscripted into a gang because they target boys his age

- Julissa: has many fond memories of growing up there and visiting her cousins and the natural beauty and community-oriented culture of El Salvador. In some ways would love to go back to visit, but is unsure because she's worried about the violence. Some places are okay, she says, but unless you live there it's hard to have a feel for what neighborhoods are safe and what ones aren't.

- Mariela: Not sure about her memories overall, though she has fond (and disturbing) memories of her dating life in El Salvador in high school. Her husband, on the other hand, sounds like he had a super traumatic life before meeting and marrying Mariela that included his mom dying when he was a kid, living on the street, starving, and working exceedingly dangerous jobs as a child laborer.

They want their kids to have better economic and social opportunities than they did, including opportunties to go to collge. They rightly view bilingualism as a key to opening up lots of doors for their kids -- even more than if the kids just speak English, and so making sure their kids learn Spanish becomes at least as valuable to this goal as making sure they learn English. (Carmen, Luciana, and Ana have all told me this explicitly.) They see their own economic and social success as key to this goal for their kids too, because they want their kids to have enough resources/opportunities, to go to good schools, to have good friends, etc. But Luciana and Ana have both said to me that it's too late for them to have all their dreams, but not for their kids.

Examples/Sources from the data:

- Interview data

- Other conversations throughout data: 
- Luciana wants kids to avoid pitfalls that Abigail fell into and find success (college is implied)

- Ana says she and her husband encourage the kids to keep at it with school and study hard so they can someday have better jobs than construction or McDonald's and better lives than their parents.

- Mariela is proud that Eduardo is enrolled at the prestigious charter school he attends he had really good grades and also won some kind of lottery to be able to go there. He'll be able to bring his younger brothers there too when they're old enough.

- Mariela would love for Paulito to do Mandarin dual immersion because Mandarin is super useful but hard to learn daw, but the school is too far away to work for her schedule of driving kids to three different schools.

- Mariela is really happy with the skills her kids learned in Kids on the Move

- Julissa wants her kids to get more education than she has

- Rocío has a rule that her kids can't drop out of HS. After high school, they can do whatever they want -- church-based service, working, college, nothing. But they have to finish at least high school. Then she trusts them to figure it out.

- Luciana is concerned about the uncertainty of immigrants in the US and how it would affect her kids if she had to go back to El Salvador - and if she would take them or not (and what would happen to them either way)

- Luciana is worried about Kimberly (and Oscar) becoming rebeldes and losing out on dreams she has for them of college and success (she's worried Kimberly could get pregnant) and wants to get them into a different junior high because the one in their district is filled with bad influences $(2 \mathrm{x})$.

- She is sad about Abigail's decisions and where they've led. Stefani became una rebelde when she got to middle school, and didn't listen to Luciana because she was "ciega y enamorada."

- Luciana is worried because her kids eat only junk food and are getting fat

- Luciana is worried about her kids navigating a world filled with evils and stresses -- a world without God.

- Rocío tells me about how Rafael is her most rebellious kid -- he's the only one who wants to drop out of hs (but she won't let him) and who doesn't have a productive plan for post-hs. It's too bad, she says, because he's really smart -- but he hates studying. He doesn't want to aprovechar the opportunity to do an associate's degree before graduating like Zara is doing, and she thinks this is too bad but doesn't want to force him.

- She's a bit worried about him pursuing boxing because he's already prone to fighting, but she doesn't want to stand between him and his passion.

Valuing kids' Spanish and bilingual abilities:

- Two conversations with Luciana about how beneficial bilingualism is

- Multiple conversations with Luciana about how sad she is the grandkids don't speak Spanish, how it's a senseless waste because it would be so easy for Abigail to use it with them

- Conversation with Carmen about how proud she is of Aaron's bilingual abilities; how he got a better- and higher-paying job than his coworkers based on this skill 
- Conversation with Julissa and separate conversation with Angel about how they're sad David isn't taking advantage of his opportunity to become truly bilingual (and they think it's a lost opportunity) and keep up his Spanish (but Daniel is and they're proud).

- Implied by Ana, Rocío, Rodrigo in various conversations

5) Other Arguments (which I didn't develop fully for this thesis)

5a) If they are enrolled in English classes, like Mariela and Rocío, they are focused more on tasks and doing them right than on actually being able to apply the skills to their English -due, in part, perhaps, to their lack of practice with book learning (at least in Mariela's case).

Evidences from the data:

- Experiences helping Mariela with her homework on multiple occasions

- Observations of Mariela and Rocío in class

- Conversations with Rocío about how she just can't motivate herself to use English in context

- Watching Eduardo "help" Mariela with her homework -- he loses patience with her, feeds her the answers word for word

5b) Participants sometimes faced discrimination in the form of Americans being unwilling to negotiate meaning with them. This was especially prevalent for Ana, who had to deal with people assuming she couldn't speak English or not understanding her even when what she was saying in English was perfectly clear. Evidences from the data:

- Conversation with PA at ENT's office (both visits) -- Ana

- Conversation with eyeglasses guy about CHIP -- Ana

5c) Participants employed a wide range of academic language features (including authoritative voice, decontextualization, detached stance, abstraction, deverbal nominalization, etc.) in their daily conversations and spoke on a wide range of complex topics. (I did not compile a list of evidences here because I decided not to focus too deeply on this argument in the thesis; however, I did code for each of these features when performing analysis on my field notes.)

Tracking participants' interactions: A quantitative look at some evidences from the data:

Total I observed of visits to...

Sam's Club - 3

1 - Luciana

1 - Julissa

1 - Luciana

Walmart - 3

1- Mariela 
1- Ana

1 - Mariela

Latinx Market - 2

1 - Mariela

1 - Mariela

Other American Store - 3

1 - Julissa (beauty supply store)

1 - Julissa (other big box store)

1 - Mariela (dollar store)

American restaurants - 2

1 - Luciana (McDonald's)

1 - Ana (Pizza Parlor) (but the order is in Spanish)

Latinx restaurants - 4

1 - Mariela (Guatemalan cafe on the phone)

1 - Luciana (Taco shop)

1 - Julissa and Mariela (Taco shop)

1 - Mariela (Jugueria)

Doctor's or dentists' office - 4

1 - Ana (ENT first visit)

1 - Ana (ENT second visit)

1 - Ana (eye doctor visit)

1 - Mariela (dentist visit for kids)

Bank - 1

1 - Luciana

Kids' school - 1

1 - Luciana

Church

1 - Luciana, Mariela, and Julissa (full service -- note this happens 3x/week)

1 - Mariela (delivering food)

1 - Carmen (cleaning - but it's only her family there)

Other

1 - Julissa taking pupusas to a client

1 - Julissa delivering something she sold on the FB marketplace

1 - Julissa and the multi-level marketing lady

1 - Ana in the taxi first time to ENT

1 - Ana in the taxi second time to ENT

1 - Ana in the taxi to eye doctor 
Work interaction

(1) - Manuel chats non-stop with other janitors

Zumba

1 - Julissa

Friend school

1 - Rocío chatting with friend all through class

1 - Mariela chatting with friend next to her throughout class

1 - Mariela giving girl from class a ride home, chatting on the way

Friend outing

1 - Julissa, Valery, and Mariela to Zumba and then taco shop

Church people outing/event

1 - the pupusa sales event (she talked about/prepared for this two other times, but I only went once)

Friend phone conversation - 3

1 - Mariela (talks to cuñada for at least 45 mins.. still talking when I leave)

1 - Carmen (talks to friend - maybe Adriana, her sister? - for 15-ish mins maybe

1 - Mariela (again talks to cuñada for 30 mins)

Friend visit - 3

1 - Julissa chatting for a long time with elderly Guatemalteca client

1 - Rocío chatting with her "adopted daughter" outside high school

1 - Carmen (Lucy's birthday party, with Adriana and husband arriving early to chat)

Friend encounter in community - 2

1 - Mariela (friends in Walmart)

1 - Mariela (Mexican market)

Engaging with Spanish media

1 - Luciana (predicaciones)

2 - Mariela (listening to Bethel Spanish chanel music in car)

(3) - Mariela (says she listens to lots of music while cooking)

4 - Luciana (predicaciones)

5 - Carmen (The Shack in Spanish) (actually an English show but with Span settings)

6 - Luciana (predicaciones)

Engaging with English media (self) (kids or kids-ish)

1 - Luciana (Beverly Hills Chihuahua)

2 - Luciana (Mowgli - BUT changes to Spanish setting after few mins)

3 - Julissa (cartoons)

4 - Julissa showing me her favorite songs (+ Latinx music awards) 
5 - Julissa's kids watching lots or cartoons

(Engaging in social media: making social connections with Latinx friends both here and back in their home countries, scrolling through or showing me Spanish memes and FB quotes, engaging with the FB marketplace or lotto community.) 


\section{Appendix 4: Data and Recording Indices}

\section{DATA INDEX:}

Luciana:

L - No Recording (6)

$5 / 14-3 h$

- We talk at Luciana's house briefly

- We go to school and have the school interaction!

-We come home and make lunch with Kimberly and eat

L - No Recording (5)

$4 / 24$ - 1 h 40 mins

- Luciana and I talk in the living room for a while, then make food in the kitchen.

- This observation features lots of interactions between $L$ and Oscar, $L$ and Kimberly, and Kimberly and Oscar (including the fight between them, and Luciana's comment about them saying bad words in English)

L - No Recording (4)

$4 / 9$ - 2 h 40 mins

- Luciana and I talk in the kitchen and living room

- Minimal interactions with the grandkids and Abigail (and between Luciana and Abigail)

- Luciana talks on the phone to the insurance company in English

L10 - Recording

$3 / 26$ - 1 h 30 mins

- Luciana and I go to Sam's Club with all kids and grandkids (who all have to come because of fumigation at house)

- Interaction (English) with cashier over two credit cards 
- Interactions and fights (English and Spanish) with kids

- Hot dogs

L9 - Recording

$3 / 21$ - 2 h 30 mins

- Luciana makes food and interacts in kitchen and living room

- Interactions with kids and grandkids (and amongst kids), some in English

L8- Recording

L7- Recording

L6 - Recording

$2 / 28$ - 2 h 55 mins

- Luciana and I go to taco shop to pick up food for Rodrigo -- restaurant exchanges in Spanish

- I go with Luciana to work with Rodrigo, laying carpet at house

- English exchange between American contractor and Rodrigo

- Spanish exchanges between me and Rodrigo -- comments on Kimberly and Oscar's dual culture

L5 - Recording

L4 - Recording

$2 / 19-3 h$

- I spend this entire time in Luciana's living room. Stephanie and her husband are there for part of the time, and Luciana's granddaughters are there the whole time and play into our interaction

L2 - Recording

L1 - Recording

$2 / 12-3 h$

- I spend this entire time in Luciana's living room with her and the various kids (Ashley and Yahir, Stephanie, the grandkids). 
- We watch two movies (Beverly Hills Chihuahua and Mowgli)

- Good (but chaotic) data on interactions between the various kids and between the kids and Luciana

L - No Recording (3)

$1 / 29-2 h$

- I meet Luciana at the Iglesia Cristiana Pentecostal and stay for the service with her.

L - No Recording (2)

$1 / 23$ - 3 h 50 mins

- Luciana and I go to Sam's Club to shop (including for ingredients for pupusas for the church event)

- Then we go to McDonald's and she orders at the drive through

- Then we go home and I talk to her there for a while

- It's just us two the whole time.

L - No Recording (1)

$1 / 17$ - 2 h 26 mins

- I meet Luciana for the first time. We sit in her living room talking the whole time I'm there.

- Other than her husband being there for a couple mins, it's just us two.

\section{Mariela:}

M11 - Recording

$4 / 2$ - 3 h 40 mins

- Home interactions with kids (English and Spanish)

- Helping $\mathrm{M}$ with her homework assignments 
M10 - Recording

$3 / 27-2 h$

- Car interactions with M -- listening to her phone conversation with a friend from church (Spanish) about blessing a sick friend to be healthy

- Walmart visit -- interaction over diet pills

- Running into Latinx friends at Walmart

- Eating, spending time at home, chores, chatting (no kids -- morning visit)

M9 - Recording

M8 - Recording

$3 / 20$ - 4 h 14 mins

- I visit $\mathrm{M}$ at home

- Picking kids up from school, dropping Eduardo off at church for youth activity

- Interactions at home with $\mathrm{M}$ and kids, eating and cooking

- Looking at pics, memes, songs on phone

- Again I help M with her English homework assignments

M7 - Recording

$3 / 5$ - 3 h 40 mins

- I visit $\mathrm{M}$ at home while she cooks for homeless

- Dropping off food for homeless at the Iglesia

- Picking up kids from school -- English and Spanish interactions with kids

- Eating and family time at home

- I help M with her Engish homework assignments

M6 - Recording

M5 - Recording

M4 - Recording

$2 / 26$ - 3 h 30 mins 
- School visit 1

- Recordings of class instruction ( $w /$ both teachers), exercises, etc.

- Taking classmate home

- Visit to Mexican juice bar -- Spanish interactions

- Visit to Mexican market -- Spanish interactions (also teacher mode -- showing me Salvadoran foods)

- End at M's home doing chores

M3 - Recording (+ video recording)

$2 / 20-3 h$

- Mariela and I go to the school to pick up Eduardo, who I meet for the first time (not including seeing him at the Iglesia).

- We hang out at her house while she cooks food for the Iglesia. It's mostly just us two

- Her husband comes home and I meet him.

- She orders food from Guatemalan cafe in Spanish. I learn the secrets of how to get food that's not on the menu.

- I eat with her, Eduardo, and her husband -- data from the conversation between all of us.

- She shows me pics on her phone

- I go with her to drop off the food at the Iglesia

M2 - Recording

M1 - Recording

$2 / 12$ - 3 h 40 mins

- Mariela and I begin by talking at her house (just the two of us)

- Then we go to Walmart, where she has the interaction trying to ask a worker how much something costs

- Then we go to Mexican market, where she talks to her Latinx friend from Kids on the Move

- We have the 'Kiondamo' moment

- We end by spending some time at her house while she does chores, just the two of us. 
- School visit 2 -- interacting with various students one-on-one

- Phone call with dentist, translated by Eduardo

- Dentist visit -- interactions in Spanish, English; translation by Eduardo into English

- Phone conversation with sister-in-law -- English conversation with Christian

\section{Julissa:}

J - No Recording (1)

$5 / 14-35$ mins

- Julissa and I chat at her house about her cancer scare. Interesting data about the free clinic she's on her way to attending.

J10 - Recording

$4 / 25$ - 3 h 30 mins

- Home visit while J looks after Kevin

- English TV in background

- YouTube videos, music videos, music awards

- She tells me about her childhood, shows me photos of her and her cousins and of El Salvador

- Tells me about fears of returning

\section{J9 - Recording}

J8 - Recording

4/17 - 2 h 40 mins

- We pick up Mariela's kids from school and I talk to them in the car, then we go home and wait for Mariela to pick them up

- We go to Sam's Club with Kevin and the little girl Julissa is tending

- We get home and unpack the groceries and have cheesecake -- some interaction with Julissa's husband and kids

- The multi-level marketing lady comes, we talk with her, and then Julissa saves me from her 
J7-Recording

3/26 - 3 h 50 mins

- Drive to pick up Valery and her daughter from their apartment -- Spanish interactions in car

- Zumba at the Catholic church

- Lunch at taco shop with J, Valery, and me -- they call Mariela and she joins us

J5 - Recording

$3 / 6-3 h$

- Home interactions with Kevin and the TV

- I hang out and talk to her as she goes about home chores and tending small kids

J4 - Recording

J3 - Recording

$2 / 20-3$ h 5 mins

- We drive to school to pick up David from his shadow day

- We go home and I talk to her while she makes pupusas

- I go with her to deliver them to the old lady who ordered them (but I don't get to go in)

- We go home again and she shows me pictures and music videos. I am mostly just talking to her but also to her kids a little bit.

$\mathrm{J} 2$ - Recording

J1 - Recording

$2 / 14-3 h$

- I hang out in the living room with Julissa and her three kids, who are quietly watching TV

- I talk with Julissa in the kitchen

- Dinner is ready and I talk with Julissa, her husband, and all her kids while they eat. Good data on the family's interactions with each other and with me. 
Ana:

(A8 - Recording)

(A7 - Recording)

$6 / 10-3 h$

- We talk at Ana's house

- Then we go with Melanie to the eye doctor in Isaac's taxi

- (No recording of the part in Isaac's taxi)

- Good interactions at the eye doctor's, including the exchange over CHIP

- We go home in Isaac's taxi

A6 $-4 / 11$

$4 / 11$ - 2 h 30 mins

- I talk to Ana while she cooks and while she sits on the couch

- I play with the kids (w/o Ana) for a long time

A5 - Recording

$3 / 7$ - 2 h 30 mins

- We start out at Ana's house

- Then we go back to the ENT for Francisco Jr.'s check-up, again in Isaac's taxi

A4 (Isaac) - Recording

A3 - Recording

$2 / 28$ - 2 h 55 mins

- We go to the ENT in Isaac's taxi -- good interactions with Isaac

- The whole fiasco of setting Francisco Jr.'s nose -- good interactions with the doctor and the front desk lady

- We go eat at Pizza Parlor -- good interactions with Ana and her kids (Natalie and Francisco)

- We go to Walmart 
- We go home in Isaac's taxi

A2 - Recording

A1 - Recording

$2 / 18$ - 1 h 40 mins

- I talk to Ana in her house as she makes dinner

- I eat dinner with her and all her kids

A - No Recording (1)

$2 / 5-1 h$

- I meet Ana and talk to her while she cooks and while we sit at the table.

- Mostly it's just us but we also talk briefly to her husband and kids

- Some good interactions between Ana and her daughter Melanie.

\section{Rocío:}

(R6 - Recording)

$5 / 9-1$ h 55 mins

- We spend time at home where I interact with Manuel (husband) and a bit with the kids

- We take Manuel to work at taco shop and talk on the way there

- Rocío and I talk on the way back in the car

R5 - Recording

R4 - Recording

$5 / 1$ - 2 h 10 mins

- We go to the high school and have the debacle of her kids and the fist fight

- We go home and drop of the high schoolers and get Zara

- We pick Nicole up from school

- We go to drop Zara off at the bus stop 
- We get gas at the gas station

- We go home and I help her make food and then we eat with all the kids

R - No Recording (2)

ESL School

$4 / 15-\sim 2 h$

- I observe her in class with Alyssa (teacher) and then with Travis (teacher)

- I chat with her and an older woman named Rocio during class

- I follow her home and we talk on the couch for a bit

R3 - Recording

$4 / 10-45$ mins

- I hang out in the kitchen with Rocío and a whole bunch of teenagers - most of my interaction is with the teenagers

- Rocío and group leave for the middle kid's boxing match

R2 - Recording

R1 - Recording

$3 / 6-2$ h 35 mins

- School observation

- I observe her in class with Ben (teacher) and then Carolyn (teacher)

R - No Recording (1)

2/25/19 - 1 h 20 mins

- I meet Rocío and Manuel and talk to them in their living room 


\section{Carmen:}

(C3 - Recording)

$5 / 11-3 h$

- E and I watch The Shack in Spanish

- She gets a phone call and chats for a while

- Her sister and brother-in-law arrive and we talk all together

- A whole bunch of other people arrive and we have Laura's birthday party -- I am mostly talking to the brother-in-law and a guy from Colombia (and a little bit to his sister and her husband, and occasionally to Carmen, who is serving)

\section{C2 - Recording}

$5 / 4$ - 1 h 45 mins

- $\mathrm{E}$ is not at her house when I arrive, so I meet her at the Iglesia (she's cleaning it), which is where the recording starts

- We clean the church (me and her kids)

- Interaction in English with the homeless people

- I take her to run errands (to a friend's house, the soup kitchen -- interesting interaction at the soup kitchen)

- We go home and talk at her house for a little while

C1 - Recording

$3 / 29$ - 1 h 40 mins

- I talk to $\mathrm{E}$ alone at her house in the kitchen

C - No Recording (1)

$3 /-1 h$

- I meet her and she introduces me to her kids. Kimberly and Oscar are also there.

- We talk in her kitchen 


\section{RECORDING INDEX:}

Luciana:

$\mathrm{L} 10-3 / 26 / 19$

L9 - 3/21/19

L8 - 2/28/19

L7 - 2/28/19

L6 - 2/28/19

L5 - 2/19/19

L4 - 2/19/19

L2 - 2/12/19

L1 - 2/12/19

(+ 6 non-recorded, three at the beginning and three at the end)

Mariela:

$$
\begin{aligned}
& M 11-4 / 2 / 19 \\
& M 10-3 / 27 \\
& M 9-3 / 20 \\
& M 8-3 / 20 \\
& M 7-3 / 5 \\
& M 6-2 / 26 \\
& M 5-2 / 26 \\
& M 4-2 / 26 \\
& M 3-2 / 20 \\
& M 2-2 / 12 \\
& M 1-2 / 12
\end{aligned}
$$


(+ a partial video recording)

Julissa:

$\mathrm{J} 10-4 / 25$

J9-4/17

J8-4/17

J7-3/26

$\mathrm{J} 5-3 / 6$

$J 4-2 / 20$

$J 3-2 / 20$

$J 2-2 / 14$

$\mathrm{J} 1-2 / 14$

(+ 1 short non-recorded at end)

Ana:

(A8 - 6/10/19)

(A7 - 6/10/19)

A6-4/11/19

A5 - 3/7/19

A4 (w/ Isaac) - 2/28/19

A3 $-2 / 28 / 19$

A2 - 2/18/19

A1 - 2/18/19

(+ 1 non-recorded at beginning) 
Rocío:

(R6 - 5/9/19)

R5 - 5/1/19

R4 - 5/1/19

R3 - 4/10/19

R2 - 3/6/19

R1 - 3/6/19

(+ 3 non-recorded -1 at beginning and 2 from language school)

Carmen:

(C3 - 5/11/19)

C2 $-5 / 4 / 19$

C1 - 3/29/19

(+ 1 non-recorded at beginning) 


\section{Appendix 5: Codes and Sub-Codes (Codebook)}

A1 - Reasons for wanting to learn English

A2 - How participants perceive English and learning English

A3 - Language-related desires for kids

A3a - Examples of kids utilizing English

A3b - Examples of kids utilizing Spanish

A3c - Examples of kids speaking Spanglish

-- make note of with whom, to whom, where, and why

Other desires related to kids:

E - Wanting kids to preserve their culture and heritage

Ela - Talking explicitly about this desire

E1b - Showing it through action

F - Social and other situations of kids

F1 - Who are kids' friends/social circles/dynamics

F2 - Good vs. bad influences on kids (shown or spoken of by parents)

B - Tracking partiipants' language use in situated, authentic contexts

B1 - Situations where no English is necessary / only Spanish used

B2 - Situations where participants successfully navigate using English

B2a - Using strategies (formulaic expression/prefabricated patterns, one-word

responses, minimizing interactions, deixis, etc.)

-- make note of which strategy used

B2b - Using "natural" or unscripted English

B3 - Situations where participants start out okay with English but it gets weird

B4 - Situations where participants get by in English using translation or other help

B5 - Situations where they need English and do not succeed

B5a - In writing

B5b - In speaking

C - School-based interactions

C1 - Difficulties with English in school situations

C1a - Successes with English in school situations

C2 - Difficulties with English in homework situations

G1 - Negotiaton of meaning with English-speaking interlocutor

G2 - Encountering prejudice with English-speaking interlocutor

$\mathrm{K}$ - Academic language feature used (in Spanish)

-- note feature: decontextualization, authoritative voice, detached stance, deverbal

nominalization, abstraction, etc.

Q - Other language-rich moment (in Spanish)

$\mathrm{O}$ - Evidence of women's desire for connection/company/conversation

$\mathrm{P}$ - Perceptions of current situation 
Appendix 6: Inventory of all individuals (pseudonyms) that appear in the study and how they relate to the participants

1. Luciana

Rodrigo

Abigail

Vincent

Lucy

Maxine

Amanda

Kimberly

Oscar

2. Mariela

Paul

Eduardo

Christian

Paulito

Julissa

Angel

David

Daniel

Kevin

Valery

Carmen

Edgar

Aaron

Alexander

Laura

Adriana

Luis

Ana

Francisco Sr.

Francisco Jr.

Sebastian

Diego

Melanie

Andres

Natalie

Isaac
(Participant, age 48)

(Husband)

(Daughter, age 26)

(Grandson, age 7)

(Granddaughter, age 6)

(Granddaughter, age 3)

(Granddaughter, age 2)

(Daughter, age 12)

(Son, age 10)

(Participant, age 35)

(Husband)

(Son, age 15)

(Son, age 9)

(Son, age 5)

(Participant, age 29)

(Husband)

(Son, age 13)

(Son, age 10)

(Son, age 2)

(Friend)

(Participant, age 49)

(Husband)

(Son, age 23)

(Son, age 14)

(Daughter, age 11)

(Sister)

(Brother-in-Law)

(Participant, age 38)

(Husband)

(Son, age 16)

(Son, age 14)

(Son, age 12)

(Daughter, age 9)

(Son, age 6)

(Daughter, age 4)

(Taxi Driver/Friend) 
Rocío

Manuel

Zara

Rafael

Jonathan

Nicole
(Participant, age 43)

(Husband)

(Daughter, age 18)

(Son, age 16)

(Son, age 15)

(Daughter, age 9) 